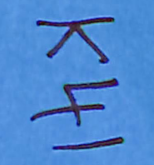

JESSICA DOROTHY KERR

$\frac{\pi}{4}$

\title{
IMMUNISATION AND THE LAW: SLIPPERY SLOPE TO A HEALTHY SOCIETY
}

LLB (HONS) RESEARCH PAPER

LAW AND SOCIAL POLICY (LAWS 527)

FACULTY OF LAW

VICTORIA UNIVERSITY OF WELLINGTON

2005 


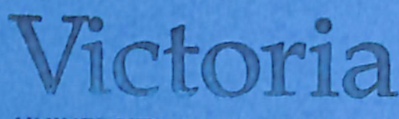

UNIVERSITY OF WELLINGTON

Te Whan Nananga

o se Upoler " "ka a Mãui

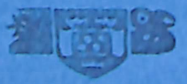

\section{LIBRARY}




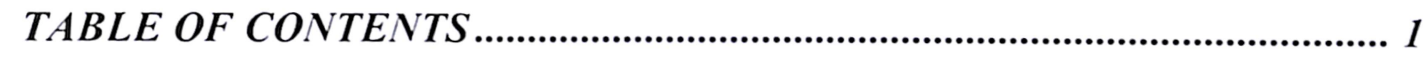

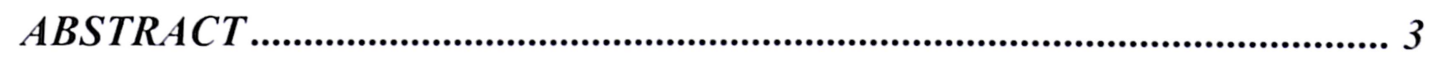

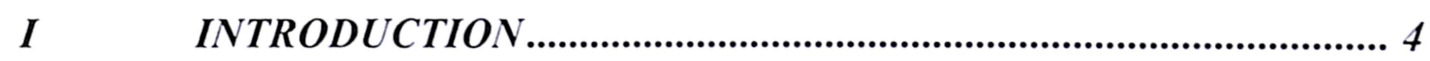

II INDIVIDUAL INTERVENTION, PUBLIC GOAL ....................... 6

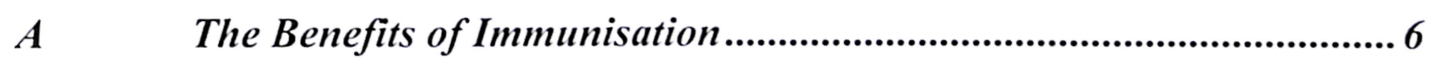

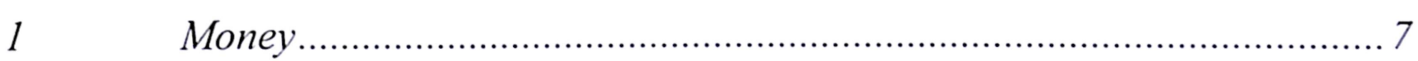

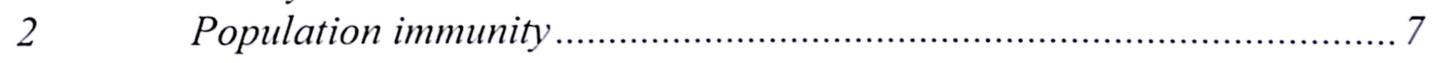

B Immunisation: The Down Side?...................................................... 9

$1 \quad$ Adverse events following immunisation ............................................ 9

2 Opposition to immunisation programmes ..................................... 11

C Why the Law Gets Involved …............................................................... 13

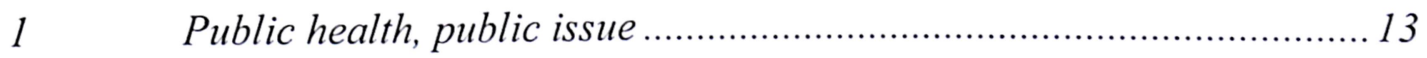

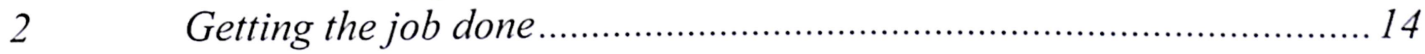

D Dilemmas in Immunisation Law ....................................................... 15

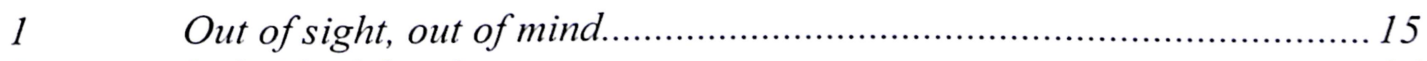

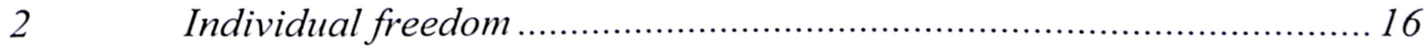

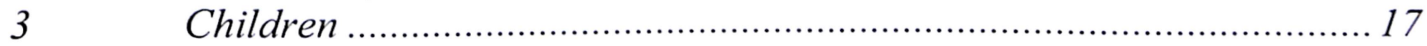

III IMMUNISATION IN NEW ZEALAND ..................................... 18

A Immunisation Policy ..................................................................... 18

B Role of the Law................................................................................... 19

$1 \quad$ Health (Immunisation) Regulations 1995 ..................................... 19

C The Gulf between Policy and Reality ................................................... 20

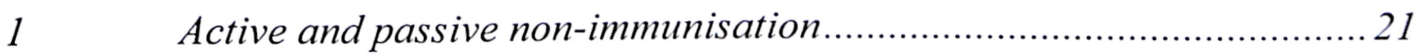

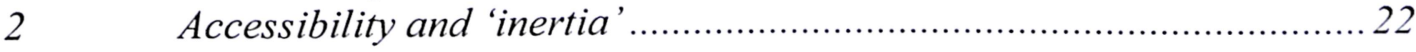

D Change in the Air?................................................................................ 24

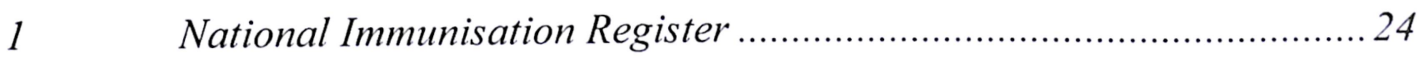

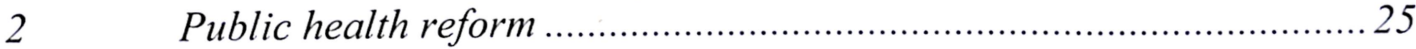

E Summary ...................................................................................... 27 
The Right to Refuse Immunisation? ................................................ 28

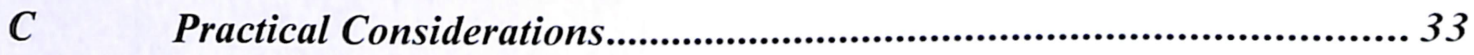

How do you enforce an immunisation law? .................................. 34

The Content of Informed Decisions ................................................... 39

The 'right' of parents to make immunisation decisions .................... 41

Striking a balance ............................................................... 43

Providing information............................................................ 44

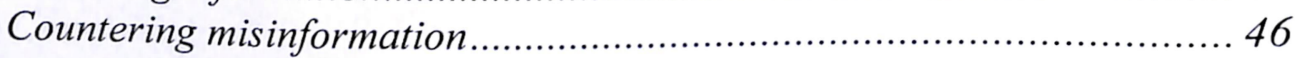

B Statutory Exemptions and the Illusion of Choice...............................48

Exemption, objection or abstention? .......................................... 49

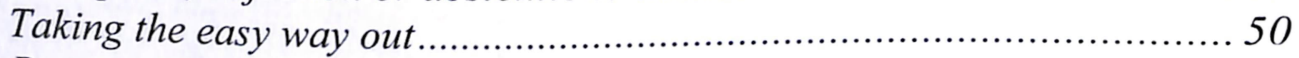

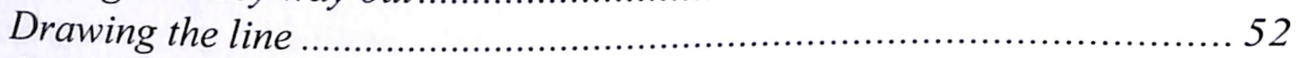

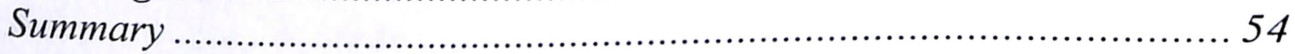

C Risk Communication and Adverse Events ....................................... 55

VII IMMUNISATION AND BENEFICIARIES ................................58

A Why Single Out Beneficiaries?.......................................................58

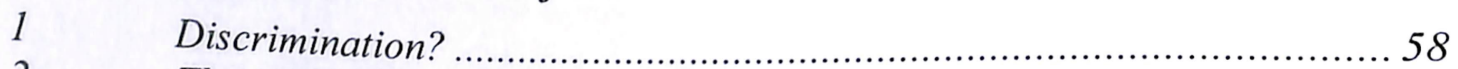

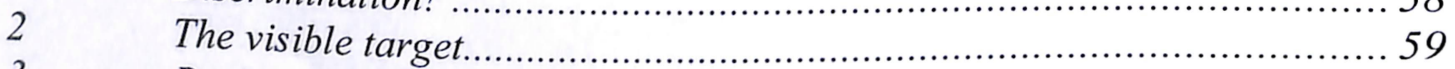

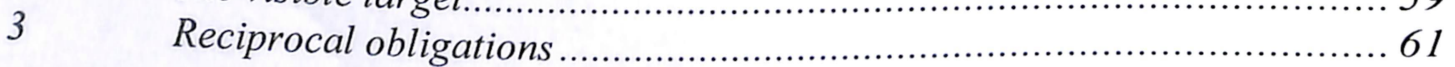

B Immunisation as a Reciprocal Obligation ...................................... 62

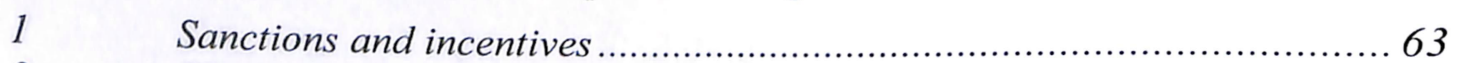

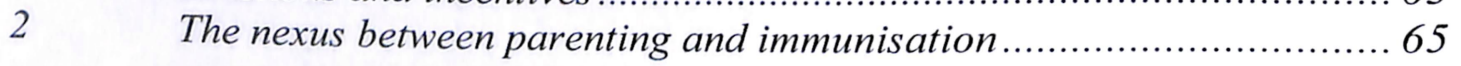

C To Obligate as Others are Obligated ..................................................67 67

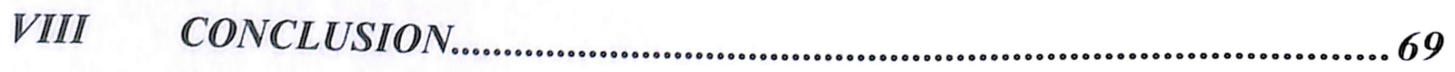

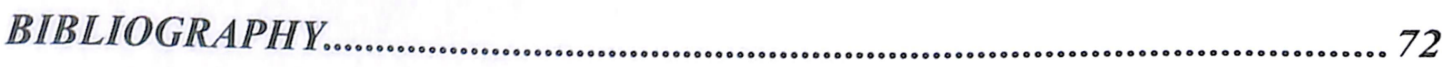




\section{ABSTRACT}

The immunisation of children against communicable diseases is a crucial public health intervention with both individual and collective outcomes. Current New Zealand immunisation policy prioritises parental autonomy, but has not succeeded in actively targeting all of the factors that prevent parents from ever making informed immunisation decisions. Consequently, our coverage rates are unsatisfactory both in absolute (by reference to the goal of 'population immunity') and relative terms. In order to have a realistic chance of meeting the Ministry of Health's optimistic coverage targets, it is necessary to consider whether New Zealand's comparatively weak immunisation law could be strengthened to eliminate the phenomenon of 'passive' non-immunisation without fatally undermining the decision-making capacity of parents. If this is not possible, then either the goal of population immunity or the prioritisation of individual choice must be abandoned. Of the three options for law reform explored by this paper, two are thought to be unworkable because they would, or should, be perceived as failing to achieve the delicate balance between individual freedom and public good. These are, first, a universal mandatory immunisation requirement, which may be justifiable in principle but would almost certainly encounter prohibitive public opposition; and, secondly, a targeted law that would require beneficiaries to make active decisions about immunisation, and (it is submitted) represents an unwarranted misuse of the vulnerability of those dependent upon taxpayer support. The reform option recommended is more moderate and more equitable. Creating a legal presumption in favour of immunisation, at the point of entry into primary school, would shift New Zealand from its current paradigm of 'informed consent' - whereby parents must actively opt in to immunisation - to a United States-style model that required parents who wished to opt out of immunisation to undergo a 'informed refusal' process. The stringency of this process would depend upon the degree to which policy-makers were satisfied that only those parents whose deeply held convictions prevented them from being open to persuasion were attempting to invoke it. Unless the size of the anti-immunisation lobby significantly increases, it is suggested that an informed refusal requirement could successfully tackle the problem of passive nonimmunisation, thereby discharging the State's responsibility to further the interest of all New Zealanders in achieving and maintaining population immunity levels.

\section{Word Length}

The text of this paper (excluding abstract, table of contents, footnotes and bibliography) comprises approximately 16,500 words.

Immunisation-Public health-Children-Reciprocal obligations 
Childhood immunization policy ... contemplates numerous complex, contentious, and controversial themes: a state's interest in protecting public health must be balanced against an individual's medical treatment considerations; concepts of informed consent and personal autonomy must be balanced against state mandates; minorpatients' rights and public interests must be balanced against parental rights; and religious and personal philosophies must be balanced against science and medicine. ... The prospect of harmoniously resolving all of these concerns appears daunting.

The New Zealand government has a commitment, shared with governments around the world, to childhood immunisation as one of the most cost-effective and successful public health interventions of all time. ${ }^{2}$ The National Immunisation Programme aims to ensure that immunisation is free and accessible to all New Zealanders, so that parents may take advantage of one of the greatest opportunities to safeguard their children's future that modern medicine can provide.

Unfortunately, less New Zealand parents choose to submit their children to immunisation than in almost any other Western country. As a result of our comparatively low immunisation rates, children and adults continue to die of diseases that could be successfully controlled, and in many cases eradicated altogether, through immunisation. Notwithstanding optimistic policy objectives and continuing Ministry of Health initiatives, the government has consistently failed to secure the immunisation of enough children to attract the collective benefits associated with "population immunity". 3

\footnotetext{
1 Ross D Silverman "No More Kidding Around: Restructuring Non-Medical Childhood Immunization Exemptions to Ensure Public Health Protection" (2003) 12 Ann Health L 277, 278. ${ }^{2}$ See Ministry of Health (National Immunisation Programme) Immunisation in New Zealand: Strategic Directions 2003-2006 (Wellington, 2003) 1; British Medical Association Childhood Immunisation: A Guide for Healthcare Professionals (British Medical Association Publications Unit, London, 2003) 1; United Kingdom Department of Health Immunisation Against Infectious Disease (London, 1996) Foreword; Ann Kempe Immunisation Programs in NZ, USA. Canada, UK and Finland: Lessons for Australia and South Australia (1998 Churchill Fellowship Report, Canberra, 1999) 17.

${ }^{3}$ See Part II A 2 Population immunity.
} 
This paper addresses the clear opportunity which exists to improve upon New Zealand's immunisation record. It explores the prospect of drawing on the persuasive and, potentially, the coercive powers of the law to ensure that the high regard in which immunisation is held at the societal level receives appropriate weight at the point at which individual immunisation decisions are made.

The opening section introduces immunisation as a public health intervention and draws out some of the competing considerations in immunisation policy. The current New Zealand legal position is then outlined. An analysis of the causes and effects of our coverage 'gaps' reveals that while the vulnerability of some children reflects active opposition to immunisation on the part of their parents, it should be possible to achieve and sustain population immunity levels without resorting to coercion, by targeting those children whose parents have not made an informed decision either way and have accordingly been left un-immunised by our 'opt-in' system.

The rest of the paper considers various options for reforming our immunisation law, ranging from a universal mandatory immunisation law, to a more or less stringent universal 'informed choice' requirement, to a controversial proposal to link immunisation to the receipt of social security benefits. Of the various issues which would have to be navigated if coercive immunisation requirements were contemplated, the most pressing include the interplay between the individual and collective benefits and risks of immunisation; the imperative of maintaining public confidence in the integrity of State-mandated immunisation; and the allocation of decision-making rights (and responsibilities) between families and the State.

The paper concludes that law reform is both desirable and practicable. However, any initiative that either removed individual freedom of choice altogether, or had the effect of striking the balance between individual freedom and public good differently for different groups in society, would face potentially insurmountable objections. At least in the short term, the best option is to shift from an 'opt-in' to an 'opt-out' model, where children would be immunised, at the latest, at the point of school entry unless their parents successfully obtained a 
statutory exemption. This would enable the basic premise of parental autonomy to be retained, while the hard questions began to be asked about what New Zealanders consider to be adequate grounds for refusing to contribute to the development of a healthy society.

\section{INDIVIDUAL INTERVENTION, PUBLIC GOAL}

Immunisation is a preventive medical intervention that utilises the immune response of children (and sometimes adults) to build resistance to specific communicable diseases. ${ }^{4}$ Although often used interchangeably with 'vaccination', the terms are not equivalent. 'Immunisation' is, technically, the process of converting to an immune state, which can be induced either by vaccination - the controlled administration of a vaccine to trigger an immune

rsponse - or by natural infection with a disease, but does not inevitably follow from either. ${ }^{5}$

\section{The Benefits of Immunisation}

The ability to prevent individuals from contracting infectious diseases is one of the most precious that modern medicine possesses. As a direct consequence of Edward Jenner's pioneering discovery, over 200 years ago, that injection with material from cowpox provided protection against smallpox, ${ }^{6}$ vaccines have emerged as the safest, most risk-free form of medication ever developed. ${ }^{7}$ Although vaccination is performed upon individuals, the benefits of subsequent immunity extend to that individual's community and even (given the

\footnotetext{
${ }^{4}$ Australian Early Childhood Association "Immunisation"

<http://www.earlychildhoodaustralia.org.au> (last accessed 24 September 2005). 5 Ministry of Health Immunisation Handbook 2002 (Wellington, 2002) 1-2 [Immunisation
Handbook 2002]; Aphra Green "Immunisation in New Zealand: Patient Autonomy, Informed "Vanishing the Code of Rights" (2002) 1 NZ Students' Law Jnl 203, 203; Steve P Calandrillo Children?" (2004) 37 Uanis: Why are So Many Americans Opting Out of Vaccinating Their Informat" (2004) 37 U Mich J L Reform 353, 362-363; National Network for Immunization Information "Immunization Issues: Community Immunity" < http://www.immunizationinfo.org > ${ }^{6}$ United Kingdom Departm 2005) Electronic un-paginated version available only.

Foreword [Immunisation Against Infectious Disease]. ${ }^{7}$ Steven P Shelov "Parion Against Infectious Disease].

Mary E Willov "Parents Should Not Be Allowed to Opt Out of Vaccinating Their Children" in Mary E Williams (ed) Vaccinations (At Issue Series, Greenhaven Press, San Diego, 2003) $<$ http://galenet.galegroup.com> (last accessed 26 September 2005) Electronic un-paginated version available only 'Introduction'.
} 
lack of respect by infectious diseases for political borders $)^{8}$ the global population. Mass immunisation initiatives have saved hundreds of millions of lives and substantially eliminated some of the worst diseases in human history. ${ }^{9}$

\section{$1 \quad$ Money}

In the healthcare context, where resources are rarely abundant, savings in one area can lead directly to life-saving in another. In this respect, one reason for the immense value placed upon immunisation is its status as one of the most cost-effective health interventions ever developed. ${ }^{10}$ Vaccine-preventable diseases are estimated to cost 16 times more than the vaccines that prevent them, ${ }^{11}$ even without any attempt to quantify the contribution of a healthy, productive citizen compared to one permanently impaired by disease.

\section{Population immunity}

The ultimate hope of any immunisation programme is that enough people will gain immunity against a disease to effectively block its transmission within a population. ${ }^{12}$ In fact, this phenomenon (known as population or 'herd' immunity) is the only way of ensuring full protection against a disease, because no vaccine is 100 per cent effective and not everyone is physically capable of receiving all vaccinations. ${ }^{13}$ The immunity artificially stimulated by vaccines may be ineffective for the very young or old, and dangerous for those with inherited or acquired immunodeficiency and (increasingly rare) allergies to vaccine

\footnotetext{
${ }^{8}$ Ministry of Health (National Immunisation Programme) Immunisation in New Zealand: Strategic Directions 2003-2006 (Wellington, 2003) 3 [Immunisation in New Zealand].

${ }^{9}$ Calandrillo, above n 5, 358 and 369.

${ }^{10}$ See Immunisation Against Infectious Disease, above n 6, Foreword; Alan R Hinman and others "Childhood Immunisation: Laws that Work" (2002) 30 JLME 122, 122; Ann Kempe Immunisation Programs in NZ, USA, Canada, UK and Finland: Lessons for Australia and South Australia (1998 Churchill Fellowship Report, Canberra, 1999) 17; Immunisation in New Zealand, above $n 8,1$.

${ }^{11}$ Calandrillo, above n 5,380 .

${ }^{12}$ Kempe, above n 10, 18; see Calandrillo, above n 5, 420; British Medical Association Childhood Immunisation: A Guide for Healthcare Professionals (British Medical Association Publications Unit, London, 2003) 5.

${ }^{13}$ National Network for Immunization Information, above $\mathrm{n} 5$.
} 
ingredients. ${ }^{14}$ These people, as well as those for whom a vaccine simply fails, must rely on the indirect protection afforded by the immunisation of others.

Sustaining population immunity levels can lead to the eradication or elimination of most diseases. Polio and smallpox are the great, although not the only, exemplars of this process. The devastating smallpox virus was declared extinct within 170 years of the introduction of the first commercial vaccines, ${ }^{15}$ although it has now re-emerged as a potential bioterrorism threat. ${ }^{16}$ The end of wild polio - which no longer exists in the Western hemisphere, but used to cripple 350,000 children every year - is believed to be in sight. ${ }^{17}$ By contrast, the reality for diseases like diphtheria and meningococcal disease (which can be sustained by protected, asymptomatic carriers $)^{18}$ is that immunisation rates must be permanently maintained. ${ }^{19}$

In theory, not everyone needs to be immunised for any disease to be successfully controlled (if not altogether eliminated). Although exact figures vary, depending for example on the infectivity of a disease and efficacy of a vaccine, ${ }^{20}$ population immunity thresholds are generally estimated at between 90 and 95 per cent of a population. ${ }^{21}$ However, not only is vaccination not practicable for everyone, it is actively opposed by a small minority of most populations. ${ }^{22}$ The buffer provided by population immunity thresholds may only just be large enough to ensure indirect protection for these people, and may consequently be placed in jeopardy by casual decisions to ignore or refuse immunisation.

\footnotetext{
${ }^{14}$ British Medical Association, above n 12, 6; Kempe, above n 10, 18.

${ }^{15}$ Immunisation Against Infectious Disease, above n 6, Foreword.

${ }^{16}$ British Medical Association, above n 12, 2; see Ministry of Health Public Health Legislation: Promoting Public Health, Preventing Ill Health and Managing Communicable Diseases: Discussion Paper (Wellington, 2002) 35 [Public Health Discussion Paper].

${ }^{17}$ United States Centers for Disease Control and Prevention <http://www.cdc.gov $>$ (last accessed 26 September 2005); Immunisation Against Infectious Disease, above n 6, Foreword; Paul Webster “A Polio-Free World?" (2005) 366 The Lancet 359.

18 British Medical Association, above n 12, 2; Meningococcal B - Be wise, immunise $<$ www.immunise.moh.govt.nz> (last accessed 12 September 2005).
19 See Johnjoe McFadden "Injecting Some Sense" (21 January 2002) $<$ http://www.guardian.co.uk> (last accessed 20 September 2005).
${ }^{20}$ British Medical Association, above n 12, 5.
${ }^{21}$ See British Medical Association, above n 12, 5; Immunisation in New Zealand, above n 8, 2 ; National Network for Immunization Information, above $\mathbf{n} 5$.

${ }^{22}$ See II B 2 Opposition to immunisation programmes.
} 
A corollary of the impossibility of preventing the transmission of communicable disease between susceptible people is the impossibility of preventing the transmission of either the benefits or the risks of individuals' immunisation decisions. ${ }^{23}$ Yet it can be difficult for individuals to conceptualise their decision as significant in population immunity terms. The diffuse benefits of vaccination have been compared to those of voting: a "single vote, or a single vaccination, is rarely going to make any difference. ... But as with voting, if everyone stops, the system collapses." 24 Steve Calandrillo has emphasised that: ${ }^{25}$

[S]ociety cannot allow every one of its members (or even a sizeable minority) to rely on the indirect protection afforded by other vaccinated members of the herd - because then community protection unravels as all try to 'free ride' off of the benevolent acts of others.

\section{B Immunisation: The Down Side?}

$1 \quad$ Adverse events following immunisation ${ }^{26}$

No medical intervention is entirely risk-free, and immunisation is no exception. Most reported adverse reactions, like localised discomfort or low grade fever, are mild, self-limited, and anticipated by health professionals as a permutation of the immune response to an introduced antigen. ${ }^{27}$ In fact, although reports of mild reactions are common in New Zealand, ${ }^{28}$ there is research suggesting that they may occur at similar rates when a placebo instead of a live vaccine has been administered. ${ }^{29}$ In any event, considering that vaccines target

\footnotetext{
${ }^{23}$ See Ministry of Health Public Health Legislation Review: A New Public Health Legislative Framework: Discussion Document (Wellington, 1998) 15 [Public Health Legislation Review]; British Medical Association, above n 12, 5.

${ }^{24}$ McFadden, above n 19; see Public Health Legislation Review, above n 23, 15; Hinman and others, above n 10, 125.

${ }^{25}$ Calandrillo, above $\mathrm{n} 5,420$. See VI B 2 Taking the easy way out.

${ }^{26}$ The term favoured by the World Health Organisation, which does not presume a causal connection between the adverse event and the vaccination event: see Immunisation Handbook 2002, above n 5, 47.

${ }^{27}$ See Immunization Action Coalition "It's Federal Law! You Must Give Your Patients Current Vaccine Information Statements (VISs)" <http://www.immunize.org> (last accessed 24 September 2005); Shelov, above n 7 'Introduction'; Immunisation Handbook 2002, above n 5, 48. ${ }^{28}$ See Ministry of Health Well Child Tamariki Ora Health Book (Revised, Wellington, 2005) 14 [Well Child Book].

${ }^{29}$ See Immunisation Handbook 2002, above n 5, chs 3-17.
} 
diseases that can cause disability or death, genuine mild reactions - and the temporary distress caused for many children and parents by a vaccination experience - are mitigated by providers where possible, but not usually thought to warrant the cessation of immunisation initiatives. ${ }^{30}$

Although every vaccine is different, there is generally a "minute but measurable" risk of severe adverse reactions. ${ }^{31}$ The chance of suffering serious injury or death as the result of a vaccination is in almost all cases "many hundreds or thousands of times less likely than the risks associated with the diseases that the vaccines protect against. ${ }^{, 32}$ For example, there is a one in 1,000 risk of encephalopathy or death as a result of contracting measles, but the risk of encephalopathy related to the measles vaccine is one in 1,000,000 and there has never been a death conclusively associated with the vaccine. ${ }^{33}$ However, harm attributed to the vaccination of a healthy child tends to attract disproportionately more publicity - regardless of whether it was actually caused by the vaccination - than harm as a result of 'naturally' contracting a disease. ${ }^{34}$ Somewhat ironically, this distorting effect is amplified by the basic nature of immunisation programmes; it is actually a mark of their success when the likelihood of an adverse event following immunisation grows to exceed the likelihood of contracting the disease. ${ }^{35}$

\footnotetext{
30 See Immunization Action Coalition, above $\mathrm{n}$ 27; Shelov, above $\mathrm{n} 7$ 'Introduction'; Immunisation Handbook 2002, above n 5, 48.

${ }^{31}$ Chris Feutdner and Edgar K Marcuse "Ethics and Immunization Policy: Promoting Dialogue to Sustain Consensus" (2001) 107 Pediatrics 1158, 1160.

32 Immunization Action Coalition, above n 27. See Shelov, above n 7 'Introduction'; Immunisation Handbook 2002, above n 5, 260; Calandrillo, above n 5, 391.

${ }^{33}$ Immunisation Handbook 2002, above n 5, 141; Tara Ross "Parents Flock to Infect Kids at 'Pox Parties"' (7 August 2005) The Manawatu Standard <http://www.stuff.co.nz> (last accessed 26 September 2005); Douglas S Diekema and American Academy of Pediatrics (Committee on Bioethics) "Responding to Parental Refusals of Immunization of Children" (2005) 115 Pediatrics 1428, 1430.

${ }^{34}$ See Calandrillo, above n 5, 402-406; Diekema, above n 33, 1428. See generally Immunisation Handbook 2002, above n 5, 250.

${ }^{35}$ Immunisation Handbook 2002, above n 5, 250.
} 
Immunisation may be the safest and most cost-effective health intervention of all time, but as a "counter-intuitive biological process", 36 it has never been universally embraced by health consumers. ${ }^{37}$ Of the many reasons advanced for opposition to some or all vaccinations, the question of which constitute acceptable grounds for declining to participate in the collective endeavour to achieve population immunity is a difficult one. Objections to immunisation span many frames of reference - science, spirituality, culture, political philosophy - and can be based on anything from deep reservations about allopathic models of medicine to religious convictions, scepticism about the competency of government, and conspiracy theories. ${ }^{38}$

In fact, the worldwide anti-immunisation lobby is and continues to be extremely small - in New Zealand, research has consistently estimated that only one to five per cent of parents actually oppose immunisation. ${ }^{39}$ But, aided immeasurably by technological advances in information-sharing, it punches far above its weight. In particular, it has the ability to frame advice to parents and

\footnotetext{
${ }^{36}$ Arthur Allen "Opposition to Vaccination Programs is Misguided" in William Dudley (ed) Epidemics (Greenhaven Press, San Diego, 1999) <http://galenet.galegroup.com> (last accessed 26 September 2005) Electronic un-paginated version available only 'Vaccination and its Critics'.

${ }^{37}$ See generally Immunisation Against Infectious Disease, above n 6, Foreword.

${ }^{38}$ See generally Immunisation Handbook 2002, above n 5, 241-242; United States Department of Health and Human Services (Centers for Disease Control and Prevention) "Six Common Misconceptions about Vaccination and How to Respond to Them" <http://www.cdc.gov> (last accessed 26 September 2005); Diekema, above n 33. As examples of anti-immunisation material in New Zealand, see The Immunisation Awareness Society Inc <http://www.ias.org.nz> (last accessed 24 September 2005); New Zealand Anti-Vivisection Society "Vaccinations: General The Conspiracy" <http://www.health.org.nz/artltitle.html> (last accessed 24 September 2005); and New Zealand Health Trust Public Health Legislation Discussion Paper (submission to Ministry of Health, 2003).

${ }^{39}$ Ministry of Health (National Health Committee) Review of the Wisdom and Fairness of the Health Funding Authority Strategy for the Immunisation of 'Hard to Reach' Children (Wellington, 1999) 6 [National Health Committee Review]; National Health Committee "Action on Immunisation of New Zealand's 'Hard to Reach' Children" <http://www.nhc.org.nz> (last accessed 24 September 2005); Katherine Rich MP Saving the Next Generation from Welfare Dependency: Discussion Paper <http://www.national.org.nz> (last accessed 24 September 2005) 15. See generally Kempe, above n 10,44; Daniel A Salmon "Mandatory Immunization Laws and the Role of Medical, Religious and Philosophical Exemptions" (Unpublished commentary, John Hopkins Bloomberg School of Public Health, 2003) 1.
} 
legislators in a way that earns it maximum exposure while making it very difficult for those supporting immunisation to counter with reasoned argument. ${ }^{40}$

'Scientific' objections to immunisation tend to emphasise the margin of uncertainty involved in vaccination by claiming that vaccines are more or less unsafe or ineffective. ${ }^{41}$ Unfortunately, only a very small amount of this material is academically sound, and much of it is emotionally charged and completely lacking in independent corroboration. ${ }^{42}$ But even totally unsubstantiated material can be effective. ${ }^{43}$ Recent claims that the measles, mumps and rubella (MMR) combined vaccine induces autism in young children have caused MMR uptake in the United Kingdom, previously around 90 per cent, to drop dramatically notwithstanding the consistent refutation of any connection by British and international authorities. ${ }^{44}$ Powerful instincts to 'first do no harm', and to defend one's family against external interference, are easily awoken and difficult to appease.

Another set of objections to immunisation builds upon ignorance of the structure of immunisation services or general concerns about the power of central government. Suggestions that vaccination is a conspiracy for profit, or part of a strategy to gain complete control over the lives of citizens, ${ }^{45}$ may not permeate reputable media channels but can linger at an almost subliminal level, completely

\footnotetext{
${ }^{40}$ Peter McIntyre, Alison Williams and Julie Leask "Refusal of Parents to Vaccinate: Dereliction of Duty or Legitimate Personal Choice?" (2003) 178 MJA 150 (editorial) 150. See generally Kempe, above n 10, 41; Calandrillo, above n 5, 397-406.

${ }^{41}$ See generally Calandrillo, above n 5, 402-403; Immunisation Handbook 2002, above n 5, 242.

${ }^{42}$ Calandrillo, above n 5, 398 and 402-403; British Medical Association, above n 12, 15 and 19; National Network for Immunization Information "Parents: Evaluating Information on the Web" $<$ http://www.immunizationinfo.org $>$ (last accessed 24 September 2005). For a New Zealand example, see The Immunisation Awareness Society Inc "My Child Suffered an Adverse Reaction" and "Adverse Reactions: More Stories and Links" $<$ http://www.ias.org.nz $>$ (last accessed 24 September 2005).

${ }^{43}$ British Medical Association, above n 12,8.

${ }^{44}$ See Calandrillo, above n 5, 405; British Medical Association, above n 12, 15 and 20; James Meikle "Court Win for Fathers in MMR Jabs Fight" (14 June 2003) The Guardian $<$ http://www.guardian.co.uk> (last accessed 26 September 2005); Clare Dyer "Judge Overrules Mothers' Objections to MMR Vaccine" (2003) 326 BMJ 1351, 1351.

38; Allen, above n 36, "Vaccination and 38; Allen, above n 36, 'Vaccination and its Critics'; Barbara Loe Fisher "Parents Should Be Allowed to Opt Out of Vaccinating Their Children" in Mary E Williams (ed) Vaccinations (At Issue Series, Greenhaven Press, San Diego, 2003) < http://galenet.galegroup.com> (last accessed 26 September 2005) Electronic un-paginated version available only.
} 
independently of the best intentions of immunisation providers. ${ }^{46}$ It is not clear how far supporters of immunisation should be able to go in countering either misguided or deliberately misleading information that is influencing the decisions of well-meaning parents. ${ }^{47}$

\title{
C Why the Law Gets Involved \\ $1 \quad$ Public health, public issue
}

\begin{abstract}
Whilst it is true that immunisation is a clinical encounter between a health professional and a client, there is much more than that. When a health professional is immunising someone, he or she is participating in a global and national endeavour that requires a sustained, consistent approach .... . ${ }^{48}$
\end{abstract}

Public health may be usefully understood as the "process of mobilizing local, state, national, and international resources to ensure the conditions in which people can be healthy." 49 As a preventive strategy with outcomes for both an individual and their community, immunisation - far from being a private matter between consumer and provider - is a classic public health intervention. ${ }^{50}$ Indeed, along with access to clean water, it is regarded as having had the greatest global impact of any public health initiative. ${ }^{51}$

The State's general interest in improving public health is sharpened in the immunisation context for several reasons, foremost among which are that it is impossible to prevent an individual's decision about immunisation from affecting others and it is impossible for the State, particularly in a welfare state like New Zealand, to avoid the social and economic burden of preventable disease. ${ }^{52}$ It is

\footnotetext{
${ }^{46}$ See Calandrillo, above n 5, 397; Immunisation Handbook 2002, above n 5, 241.

${ }^{47}$ See VI A 2 Countering misinformation.

${ }^{48}$ Kempe, above n $10,17$.

${ }^{49} \mathrm{~W}$ Detel and others Oxford Textbook of Public Health Volume 1 (3 ed, Oxford Medical Publications, Oxford, 1997) 4.

${ }^{50}$ See National Health Committee Review, above n 39, 2; Immunisation in New Zealand, above $\mathrm{n}$ 8, 3; Public Health Legislation Review, above n 23, 15.

${ }^{51}$ Immunisation in New Zealand, above n 8, 1; British Medical Association, above n 12, 1; Public Health Discussion Paper, above n 16, 23.

${ }^{52}$ See generally Public Health Legislation Review, above n 23, 16; National Health Committee Review, above n 39, 2.
} 
against this background that the potential importance of legal initiatives in raising immunisation coverage is generally introduced. ${ }^{53}$

The staggering past successes of immunisation should not obscure the fact that most of the diseases it targets, and some it has not yet begun to fight, have not been completely eradicated or eliminated. Needless death and injury continues, and would increase exponentially if immunisation ceased: for example, 17 million people in developing countries still die each year of vaccinepreventable diseases, ${ }^{54}$ and over 2.7 million annual deaths could be expected worldwide if measles vaccinations alone were discontinued. ${ }^{55}$

The Ministry of Health suggested in 1998 that public health legislation, even (as a last resort) coercive legislation, may be appropriate where it would be more "effective and efficient than the voluntary response of society." 56 This test appears to be satisfied for immunisation. ${ }^{57}$ Most people, if pressed, would share the view of health professionals and government officials that population immunity is an important public health objective. However, broader considerations (even the long term, as opposed to short term, implications for one child) are easily overwhelmed in the immediate context of subjecting a small child to uncomfortable injections, especially when a parent's fears are fuelled by emotive media "scare stories". 58

If population immunity is in the overall interests of a country, the State should accept at least some responsibility for achieving it. ${ }^{59}$ How far this

\footnotetext{
${ }^{53}$ See generally Public Health Legislation Review, above n 23, 15; Hinman and others, above $\mathrm{n}$
10.

${ }_{55}^{54}$ British Medical Association, above n 12, 1.

Mountain State Centers for Independent Living "Support Mandatory Immunizations!"

${ }^{56}$ Public Health Legislation (last accessed 15 September 2005). See McFadden, above n 19.

${ }_{57}$ See generally Legislation Review, above n $23,16$.

${ }_{58}$ Dyer, above 44.

${ }_{59}$ See Shelove 44.

Disease Control and 7 ; United States Department of Health and Human Services (Centers for generally P Bradley "Should $<$ http://www.cdc.gov> (last accessed 26 September 2005). See Public Health Legislation Review,
} 
responsibility should extend is largely a matter of political philosophy, or the view taken of the appropriate role of the State: it could range from a decision not to hinder people from accessing immunisation, to the active promotion of immunisation, to a decision to actually implement immunisation by means of the coercive power of the law. However 'big' a population is prepared to allow its government to be, sound immunisation policy will have to acknowledge which interests are to be prioritised, and which harms to be considered acceptable, in the struggle to achieve population immunity.

\section{Dilemmas in Immunisation Law}

Policy-makers must strike a balance between individual freedom regarding immunisation (which may extend to ignoring the issue altogether) and the benefits that accrue to a child being immunised and their physical and economic community. ${ }^{60}$ Further, unless confident that immunisation can be forced on an unwilling population, they must do so without irrevocably damaging public confidence in their national immunisation programme. ${ }^{61}$ The delicacy of the State's position can be illustrated by introducing three issues which permeate the discussion throughout this paper.

\section{$1 \quad$ Out of sight, out of mind}

Perhaps the most frustrating dimension of immunisation policy is that as coverage levels begin to rise, the most compelling advertisement for immunisation - widespread and preventable injury and death - disappears from the public eye. It takes surprisingly little time for people to forget how devastating a disease like polio, to take an example no longer threatening New Zealanders at home, can be. The long-term societal goal of population immunity,

Exemption" (2002) <http://www.garynull.com> (last accessed 26 September 2005) Electronic un-paginated version available only.

${ }^{60}$ Hinman and others, above $\mathrm{n}$ 10, 122. See generally American Academy of Pediatrics "Testimony Statement of Samuel L Katz MD to the Committee on Government Reform, U.S. House of Representatives, August 3 1999" <www.aap.org/advocacy> (last accessed 13 September 2005); Kath O'Donnell "Re C (Welfare of Child: Immunisation): Room to Refuse? Immunisation, Welfare and the Role of Parental Decision-Making" (2004) 16 C Fam 213; Calandrillo, above n 5, 356 .

${ }^{61}$ See IV C Practical Considerations. 
always a difficult sell to those making decisions about the interests of an individual child, becomes an even harder sell as people no longer have first-hand experience of the threat that a disease that lies dormant within a community continues to pose. $^{62}$

Although immunisation can be "seen as an issue straddling the boundary between 'purely' medical issues and those of lifestyle choice or upbringing", ${ }^{63}$ it is often stressed that a rational immunisation decision must at least incorporate a comparison of the risk of vaccination with the risk of disease in the absence of immunisation. ${ }^{64}$ Unfortunately, due to the cumulative effect of the complexity of immunisation science, the disproportionate visibility of vaccine-related injury compared to successful immunisation, complacency as the impact of disease lessens, and the variety and vigour of messages reaching parents from the antiimmunisation lobby, most may not actually make this comparison. ${ }^{65}$ Can or should the State take it upon itself to do so, and reach a conclusion to proceed with immunisation, on their behalf?

\section{Individual freedom}

Any governmental move to implement immunisation will be seen as restricting individual freedom to at least some degree. Promotional campaigns and the advocacy, or mandating, of individual choice regarding immunisation deny citizens the freedom to avoid the issue and may be viewed as implicit coercion. Making immunisation compulsory, or limiting the grounds upon which it may be refused, places a more drastic limitation on personal autonomy and would accordingly be more problematic to implement. Chris Feudtner and Edgar Marcuse have posed several questions that would have to be confronted if the State was to consider making choices about immunisation at the societal rather than an individual level: ${ }^{66}$

\footnotetext{
${ }^{62}$ See Calandrillo, above n 5, 359; British Medical Association, above n 12, 6 and 18; Diekema, above n 33,1428 .

${ }_{63}^{63}$ O'Donnell, above n 60, 'Childhood Immunisation and the MMR Debate'.

${ }_{65}^{64}$ See for example Immunisation Handbook 2002, above n 5, 250; Kempe, above n 10, 41.

66 See Calandrillo, above n 5, 402-406; British Medical Association, above n 12, 6 and 18.

${ }^{66}$ Feudtner and Marcuse, above n 31, 1163.
} 
Is a single case prevented worth 10 immunized unwillingly? Or is the threshold 100 or even 1000? ... Conversely, if we shift to consider preventing unwilling immunization as a benefit of a recommended immunization program, how many children are we willing to see be left unimmunized inadvertently to prevent an instance of unwilling immunization?

Although vaccines can safely be administered into adulthood, and are sometimes designed for adults, children under two years of age form the primary focus of immunisation initiatives for several reasons. First, it makes sense to protect people from disease as soon in their lives as possible. Secondly, children tend to be more susceptible to, and more seriously harmed by, diseases because of their developmental status and the fact of being in close contact with similarly susceptible children in the confined environment of schools and childcare. ${ }^{67}$ Thirdly, society has a special responsibility for children, as formally acknowledged in instruments like the Convention on the Rights of the Child. ${ }^{68}$ Immunisation is generally accepted as satisfying "ethical criteria for preventative interventions in children: it is effective, minimally invasive, and associated with significant societal benefits."

This said, the "care of children is primarily regarded as part of a 'private' domain outside of the public and economic spheres", ${ }^{70}$ and the decisions of parents or guardians about their children's wellbeing are normally (appropriately) deferred to by public authorities. ${ }^{71}$ Any state-mandated immunisation programme must be prepared to prioritise, if necessary, either the right of parents to make (or

\footnotetext{
${ }^{67}$ Australian Early Childhood Association, above n 4. See Well Child Book, above n 28, 14; British Medical Association, above n 12, 6.

${ }^{68}$ Convention on the Rights of the Child (20 November 1989) 1577 UNTS 3. See Public Health Discussion Paper, above n 16, 28; British Medical Association, above n 12, 6.

${ }^{69}$ McIntyre, Williams and Leask, above n 40, 150.

${ }^{70}$ John Angus "The Code of Social and Family Responsibility as a Family Policy Initiative" in Judith A Davey (ed) Another New Zealand Experiment: A Code of Social and Family Responsibility (Institute of Policy Studies, Wellington, 2000) 137, 147. See John Eekelaar Family Law and Social Policy (2 ed, Weidenfeld and Nicolson, London, 1984) 190.

${ }^{71}$ See generally British Medical Association, above n 12, 13; McIntyre, Williams and Leask, above n 40, 150; Ross D Silverman and Thomas May "Private Choice Versus Public Health: Religion, Morality, and Childhood Vaccination Law" (2001) 1 Margins 505, 518-519; Eekelaar, above n 70, 198.
} 
refuse to make) an immunisation decision for their children or the interest of children, shared by the broader community, in receiving immunisation.

\section{IMMUNISATION IN NEW ZEALAND}

\section{A Immunisation Policy}

The prevention and control of communicable diseases is accepted as a "core public health function" in New Zealand, ${ }^{72}$ and immunisation has since its introduction in 1926 assumed central importance in the discharge of this function. ${ }^{73}$ The Ministry of Health has overall responsibility for immunisation policy and delivery, with potentially conflicting roles including vaccine purchase, monitoring of new vaccines and adverse events, auditing of providers, and "strategies for improving coverage". 74

Currently, the National Immunisation Schedule protects against nine diseases, six of which are thought to be capable of eventual elimination, ${ }^{75}$ and vaccinations are administered to children at the ages of six weeks, three, five and 15 months, and four and (in one instance) 11 years. ${ }^{76}$ The most recent policy objective is to "ensure the delivery of safe and effective vaccination programmes to all children and their families in New Zealand". ${ }^{77}$ However, the official immunisation target is 95 per cent (not 100 per cent) of children by the time they reach the age of two years. ${ }^{78}$

\footnotetext{
${ }^{72}$ Ministry of Health Public Health Legislation Review: A New Public Health Legislative Framework: Discussion Document (Wellington, 1998) 37 [Public Health Legislation Review]. See generally Convention on the Rights of the Child (20 November 1989) 1577 UNTS 3, art 24 ${ }_{73}$ See Miniticulart 24(2)(c) and (e)).

Strategic Ministry of Health (National Immunisation Programme) Immunisation in New Zealand: Ministry Directions 2003-2006 (Wellington, 2003) Foreword [Immunisation in New Zealand]; Handbook Health Immunisation Handbook 2002 (Wellington, 2002) 267 [Immunisation 74 andbook 2002].

${ }_{75}^{74}$ See Immunisation Handbook 2002, above n 73, 276-277.

Immunisation Handbook 2002, above $\mathrm{n} 73,3$ and 243. The diseases are diphtheria, Haemophilus influenzae type b (Hib), hepatitis B, measles, mumps, pertussis (whooping cough), polio, rubella and tetanus.

${ }^{76}$ Immunisation Handbook 2002, above n 73, 3 and 274; Aphra Green "Immunisation in New Zealand: Patient Autonomy, Informed Consent, and the Code of Rights" (2002) 1 NZ Students' Law Jnl 203, 204.

${ }^{77}$ Immunisation in New Zealand, above n 73, 5 (emphasis added).

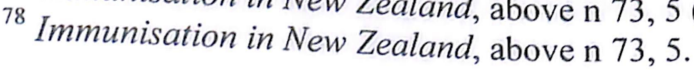


At present, "healthy public policy" in respect of immunisation is envisaged in non-coercive terms; ${ }^{79}$ in fact, an entire section of the current handbook for providers is devoted to the importance of obtaining free informed consent from parents before proceeding with vaccinations. ${ }^{80}$

\section{B Role of the Law}

By comparison with many countries that have decided, like New Zealand, that individuals should retain the basic right to make immunisation decisions (Australia and the United States, for example), we have made little positive use of the law to assist in achieving immunisation targets. Our legal system has performed an enabling rather than a prescriptive role, with a focus on removing barriers to the uptake of immunisation services (this focus has broadened recently to encompass communication strategies to counter 'inertia' and misinformation). ${ }^{81}$

\section{$1 \quad$ Health (Immunisation) Regulations 1995}

The only legal instrument in New Zealand that focuses on immunisation is the Health (Immunisation) Regulations 1995 (Regulations). In summary, the Regulations link childhood immunisation to education by "requir[ing] early childhood centres and primary schools to require information from caregivers in the form of immunisation certificates regarding the immunisation status of children." $" 82$

Encouraging parents to make an informed choice about immunisation is a stated purpose of the Regulations, ${ }^{83}$ and the current Immunisation Handbook states that parents "must" now make a choice. ${ }^{84}$ However, the only obligation

\footnotetext{
${ }^{79}$ See Immunisation in New Zealand, above n 73, 19.

${ }^{80}$ Immunisation Handbook 2002, above n 73, 32-35.

${ }^{81}$ See Immunisation Standards 2002, Standard 10 in Immunisation Handbook 2002, above n 73, 281; Immunisation in New Zealand, above n 73, 6 and 19.

${ }^{82}$ Green, above n 76, 209.

${ }^{83}$ Health (Immunisation) Regulations, reg 3.

${ }^{84}$ Immunisation Handbook 2002, above n 73, 283; see Ministry of Health Well Child Tamariki Ora Health Book (Revised, Wellington, 2005) 14.
} 
placed upon caregivers of children (in contrast to the various obligations placed upon educators $)^{85}$ is to provide a completed immunisation certificate if asked to do so. Actually making an informed choice about immunisation, which should logically precede the issuing of a certificate by a health provider, is neither mandated nor facilitated. ${ }^{86}$ Even the provision of information remains on a de facto 'opt-in' basis, given that there is no practical incentive for parents to comply with an educator's request. Presenting a certificate of non-immunisation (which does not have to include reasons) and simply failing to present a certificate have the same result, in that the relevant child may be temporarily excluded from school in the event of an outbreak of disease. ${ }^{87}$ The Regulations expressly do not make enrolment in childcare or school contingent upon the production of a certificate, in consideration of the fact that education is both a protected right and, for children over six, a legal obligation under the Education Act $1989 .^{88}$

\section{The Gulf between Policy and Reality}

The short version of New Zealand's immunisation story is that, notwithstanding a "dramatic decline" in vaccine-preventable disease since the introduction of the National Immunisation Programme, ${ }^{89}$ we have consistently failed, and will fail again this year, to reach official immunisation targets. ${ }^{90}$ Although aspects of our immunisation delivery structure have been praised by foreign commentators, ${ }^{91}$ the bottom line is that compared "with other developed countries our immunisation coverage at age two years is low ... and New

\footnotetext{
${ }^{85}$ See Health (Immunisation) Regulations 1995, regs 4, 5, 8, 9 and 10(2).

${ }^{86}$ See Green, above n 76, 209.

87 See Ministry of Health Consent in Child and Youth Health: Information for Practitioners (Wellington, 1998) 25; Ministry of Health Progress on Health Outcome Targets 1998 (Wellington, 1998) 80 [Progress on Health Outcome Targets 1998].

${ }^{88}$ Health (Immunisation) Regulations 1995, reg 12. See Education Act 1989, ss 3 and 20; IV C 2 The school entry issue.

${ }_{90}^{89}$ Immunisation in New Zealand, above n 73, vi.

${ }^{90}$ Immunisation in New Zealand, above n 73, vi and 2; Progress on Health Outcome Targets 1998, above n 87, 75-80.

${ }^{91}$ See Ann Kempe Immunisation Programs in NZ, USA, Canada, UK and Finland: Lessons for Australia and South Australia (1998 Churchill Fellowship Report, Canberra, 1999) 25-26, 28-29, 49 and 53. See VI C Risk Communication and Adverse Events.
} 
Zealand rates of vaccine-preventable disease are consequently higher." 92 Because our coverage is well below population immunity thresholds for diseases like measles, which researchers have targeted for global eradication within the next decades, ${ }^{93}$ epidemics are still a real threat.

It is important to understand why our immunisation policy has not led to the achievement and maintenance of population immunity levels for most diseases, in order to consider how it might be improved. Considering our government's emphasis on parental choice, the natural conclusion might be that parents have simply chosen to decline to participate in immunisation. If so, then unless policy-makers can find a way to change their minds, either the policy objective of population immunity or the prioritisation of parental choice must be abandoned.

However, the explanation is both less simple and, arguably, less pessimistic than that. As discussed above, there is no reason in principle why population immunity levels cannot be achieved notwithstanding the abstention of up to five per cent of the population. In practice, the large number of unimmunised children simply cannot be accounted for by the small number of parents (consistently estimated at below the five per cent threshold) who oppose immunisation. This means that there are many children whose parents do not actively oppose immunisation but are nevertheless not immunising them.

On one view, the State has failed these 'passively' un-immunised children: their increased vulnerability to disease is not even ameliorated, as in the case of 'actively' un-immunised children, by their parents having exercised their right to freedom of choice. From another perspective, the phenomenon of

${ }^{92}$ Immunisation in New Zealand, above n 73, 1. See Ministry of Health Public Health Legislation: Promoting Public Health, Preventing Ill Health and Managing Communicable Diseases: Discussion Paper (Wellington, 2002) 33 [Public Health Discussion Paper].

${ }^{93}$ See Immunisation in New Zealand, above n 73, 3 and 17; United States Department of Health and Human Services (Centers for Disease Control and Prevention) "Measles Mortality Reduction and Regional Global Measles Elimination" < http://www.cdc.gov> (last accessed 26 September 2005). 
'passive' un-immunisation is a hopeful one: it should be possible to achieve our population immunity targets, without resorting to coercion, by focusing on those children who are passively rather than actively un-immunised.

\section{Accessibility and 'inertia'}

Of course, passive non-immunisation cannot be eliminated while practical or systemic barriers to accessing immunisation services exist. ${ }^{94}$ However, the legal foundation for accessible immunisation has been laid. The fact that all routine childhood vaccines are free, ${ }^{95}$ for example, not only makes immunisation affordable in absolute terms but should prevent parents from making the mistaken decision that it should be prioritised below other services for financial reasons. Although accessibility concerns are (appropriately) the subject of ongoing Ministry initiatives, ${ }^{96}$ and would have to be addressed if sanctions for non-compliance with immunisation requirements were contemplated, they are not viewed as the root cause of passive non-immunisation in New Zealand.

Instead, the term "parental inertia" has been coined to describe parents who may not be (and are almost always not) apathetic about the welfare of their children, but never get to the point of making what the State would consider to be an informed decision about immunising them. ${ }^{97}$ There is no single explanation for this 'inertia'. It has been linked to the development of hostile attitudes to government services, lack of integration - for pragmatic reasons, such as regular shifting of providers - within the health system, and anti-immunisation material that results in a hasty and/or unfounded decision against immunisation. ${ }^{98}$

\footnotetext{
${ }^{94}$ See generally Peter McIntyre, Alison Williams and Julie Leask "Refusal of Parents to Vaccinate: Dereliction of Duty or Legitimate Personal Choice?" (2003) 178 MJA 150 (editorial) 150; Chris Feutdner and Edgar K Marcuse "Ethics and Immunization Policy: Promoting Dialogue to Sustain Consensus" (2001) 107 Pediatrics 1158, 1159.

95 Immunisation Handbook 2002, above n 73, 4.

${ }^{96}$ See Immunisation in New Zealand, above n 73, 8.

${ }^{97}$ See Ministry of Health (National Health Committee) Review of the Wisdom and Fairness of the Health Funding Authority Strategy for the Immunisation of 'Hard to Reach' Children (Wellington, 1999) 30 [National Health Committee Review].

98 See generally Steve P Calandrillo "Vanishing Vaccinations: Why are So Many Americans Opting Out of Vaccinating Their Children?" (2004) 37 U Mich J L Reform 353. See II B 2 Opposition to immunisation programmes; VI A 2 Countering misinformation.
} 
Parental inertia is observed disproportionately among the "poorest, most marginalised and most vulnerable groups in our society", who are consistently associated with both poor immunisation uptake and outbreaks of vaccinepreventable disease. ${ }^{99}$ Māori and Pacific children, in particular, continue to be under-represented in immunisation statistics. ${ }^{100}$ These discrepancies have been addressed in a number of publicity, education and outreach campaigns; for example, Māori and Pacific celebrities feature prominently in the current Meningococcal B advertisements. ${ }^{101}$ However, it is not clear that the gap between Māori and Pacific and 'other' children has narrowed with time. ${ }^{102}$

It is well-documented that 'clusters' of un-immunised children hamper disease control efforts, increasing the risk of infection both within the clusters and for the wider community. ${ }^{103}$ As a result of the prevalence of passive nonimmunisation in certain socio-economic and ethnic groups, the Ministry of Health has conceded that our immunisation coverage is inequitably distributed. ${ }^{104}$ This is doubly concerning. On one hand, certain children are, through no fault of their own or (necessarily) their caregivers but due to their birth into a 'hard to reach' group, ${ }^{105}$ more likely to suffer from preventable diseases. On the other, the contribution of most children to the goals of population immunity is undermined by the continued existence of "hot spots" which allow diseases to sustain themselves. ${ }^{106}$ All New Zealanders have an interest in making our immunisation coverage more equitable.

\footnotetext{
${ }^{99}$ Immunisation in New Zealand, above n 73, 2. See National Health Committee Review, above $\mathrm{n}$ 97,1 .

${ }^{100}$ National Health Committee Review, above n 97, 7. See generally Immunisation Handbook 2002, above n 73; Immunisation in New Zealand, above n 73.

${ }^{101}$ See for example Meningococcal B - Be wise, immunise <www.immunise.moh.govt.nz $>$ (last accessed 12 September 2005). See generally Immunisation in New Zealand, above $\mathrm{n} 73$.

${ }^{102}$ Progress on Health Outcome Targets 1998, above n 87, 74; Immunisation in New Zealand, above n 73 , vi.

${ }^{103}$ See National Health Committee Review, above n 97, 2; Calandrillo, above n 98, 361; Arthur Allen "Opposition to Vaccination Programs is Misguided" in William Dudley (ed) Epidemics (Greenhaven Press, San Diego, 1999) <http://galenet.galegroup.com> (last accessed 26 September 2005) Electronic un-paginated version available only 'Risking More Outbreaks'; McIntyre, Williams and Leask, above n 94, 151.

${ }^{104}$ Immunisation in New Zealand, above $\mathrm{n} 73$, vi.

${ }^{105}$ See generally National Health Committee Review, above n 97.

${ }^{106}$ See Calandrillo, above n 98, 361.
} 


\title{
D Change in the Air?
}

\section{$1 \quad$ National Immunisation Register}

There is increasing acceptance that a national, centralised vaccination register is an "essential component" of an effective immunisation programme. ${ }^{107}$ To this end, the most significant recent policy initiative has been the development and, in 2005, the nationwide introduction of the National Immunisation Register. ${ }^{108}$ The Register is being promoted as a "key tool" by the Ministry, ${ }^{109}$ which has claimed it will eventually ensure that no children are left un-immunised for no reason: ${ }^{10}$

\begin{abstract}
It will provide accurate data on a child's immunisation status, as well as robust information on local, regional and national immunisation coverage, which is currently lacking. All children will be registered on the Register at birth (with an opt-off proviso), and immunisation data entered on it will be available to authorised health providers caring for children so they can ensure immunisations are up to date and complete.
\end{abstract}

The Ministry envisages a relatively aggressive approach to finding children who are overdue for scheduled immunisation events. Unsuccessful recalls and reminders will be followed up by referral to outreach immunisation services, and opportunistic vaccination will be enabled at any point that a child makes contact with the health system. ${ }^{111}$

However, the Register is fundamentally an information-gathering mechanism, and it places no legal obligations upon parents in respect of immunisation. Interestingly, it is considered that the information held on the Register may eventually supersede the current school-entry certification

\footnotetext{
${ }^{107}$ Kempe, above n 91, 31. See Ministry of Health Overview of the National Immunisation Register (Wellington, 2004) 1 [Overview of the National Immunisation Register].

${ }_{108}^{108}$ See generally Overview of the National Immunisation Register, above n 107.

${ }^{109}$ Immunisation in New Zealand, above n 73, 7; Overview of the National Immunisation Register, above n 107, 1 .

${ }^{110}$ Immunisation in New Zealand, above $\mathrm{n} 73,7$. See Overview of the National Immunisation Register, above n 107, 3.

111 Overview of the National Immunisation Register, above n 107, 3-6.
} 
scheme. ${ }^{112}$ Rather than indicating that the Register can be viewed as an effective surrogate for immunisation laws, this demonstrates that our current 'law' is, like the Register, skewed towards monitoring rather than actually raising coverage levels.

It is hard to see the Register's successful implementation (which will not be assured for several years) as a step in the wrong direction. Having 'robust' information on actual coverage rates will enable immunisation planning to be more focused and less speculative, and a recall and reminder system may be all that is needed to secure the immunisation of children whose parents do not realise that an immunisation programme exists or is genuinely accessible. However, as the Register places no controls upon the ability of parents to withhold their children from either specific vaccinations or the entire programme, it may do little to address ostensibly deliberate non-participation that is founded upon hostility to government interventions, myths about the dangers of immunisation, or nothing in particular.

2 Public health reform

"Rumblings" about bringing our immunisation laws into line with more stringent ones in comparable countries have been circulating since the early 1990s, ${ }^{113}$ and two discussion papers (in 1998 and 2002) have now specifically raised the prospect of reform within a general overhaul of the Health Act $1956 .{ }^{114}$ Policy proposals have been approved by Cabinet, but the drafting process has stalled over the period of the 2005 general election. ${ }^{115}$

New public health legislation, according to the discussion papers, would acknowledge New Zealand's legal and social progress since the 1950s by

112 Public Health Discussion Paper, above n 92, 35. See III B 1 Health (Immunisation) Regulations 1995.

113 See New Zealand Anti-Vivisection Society "Vaccinations: General - The Conspiracy" $<$ http://www.health.org.nz/artltitle.html> (last accessed 24 September 2005) Electronic unpaginated version available only.

${ }_{114}$ Public Health Legislation Review, above n 72; Public Health Discussion Paper, above n 92.

${ }^{115}$ Public Health Discussion Paper, above n 92, 1; Baker, Gabrielle, Ministry of Health, to the author (24 March 2005) Email<Gabrielle.Baker@moh.govt.nz>. 
reflecting "widespread recognition of the importance of protecting human rights, but also agreement that giving greater value to protection of the public health [is] justified in some circumstances." 116 Although a number of provisions would address issues relating to immunisation, the two areas in which substantial reform is envisaged are emergency vaccinations and, crucially for present purposes, parents' obligations to ensure that their children are fully immunised. ${ }^{117}$

The dominant feature of the latter proposal is the suggestion that provisions in a primary Act "could be phrased generally to enable quite different regulations to be drafted". ${ }^{118}$ Regulations could implement anything from the status quo (a simple requirement to record whether a child is immunised, with no sanction for failing to do so), to certification mandating either immunisation or an acceptable reason for refusing it, to empowerment for schools to refuse a child's enrolment without appropriate certification (which would require amending the Education Act 1989). ${ }^{119}$ However, there would probably be no requirement that they would be used to implement anything at all.

It has been said that coercive public health legislation is a "last resort" in New Zealand. ${ }^{120}$ If generally empowering provisions are envisaged as a safeguard against the time when other avenues are exhausted, they risk sending the message that we are comfortable with coercive immunisation requirements now, when that is not the case. If the government considers that this time has already arrived, regulations should be required, not enabled. Better still, it should be recognised that substantive restriction of parental choice in respect of immunisation is not an appropriate subject-matter for delegated legislation. While the detail of how an initiative would be implemented can appropriately be left for regulations, the basic balance struck between individual freedom and public good should be articulated at the highest level - not only to send a message about how seriously the government takes immunisation, but to ensure

\footnotetext{
${ }^{116}$ Public Health Discussion Paper, above n 92, 6.

${ }_{117}$ See Public Health Discussion Paper, above $\mathrm{n} 92, \mathrm{x}$ and 33.

${ }_{118}$ Public Health Discussion Paper, above n 92, 34 and 86.

${ }_{119}$ Public Health Discussion Paper, above n 92, 34-35.

${ }^{120}$ See above n 56 and accompanying text.
} 
that the government is held accountable if the public disagrees with that message. $^{121}$

\section{E Summary}

When it is recognised that passive rather than active non-immunisation is the dominant cause of our failure to reach immunisation targets, it is submitted that whether or not the basic voluntary structure of our National Immunisation Programme is retained, there is room for improvement. What is required, as a corollary of making a policy commitment to achieving population immunity, is a commitment to ensuring that the 95 per cent of parents who do not appear to oppose immunisation in principle actually reach the stage of making a decision to proceed with it. The Register and the Regulations are steps in the right direction, but there is more that could be done.

\section{MANDATORY IMMUNISATION}

We have seen that in the current New Zealand policy climate, requiring parents to submit their children to immunisation is not considered to be a realistic option. ${ }^{122}$ Yet, both here and overseas, universal, State-mandated immunisation continues to be advanced by some commentators as the most efficient and effective means of protecting those people who are unable to receive immunisation (and, potentially, eradicating or eliminating diseases altogether). ${ }^{123}$

121 See generally Geoffrey Palmer and Matthew Palmer Bridled Power: New Zealand's Constitution and Government (4 ed, Oxford University Press, Melbourne, 2004) 207-212.

${ }^{122}$ See III A Immunisation Policy. For similar policy positions in comparable Western countries, see Peter McIntyre, Alison Williams and Julie Leask "Refusal of Parents to Vaccinate: Dereliction of Duty or Legitimate Personal Choice?" (2003) 178 MJA 150 (editorial) 151; British Medical Association Childhood Immunisation: A Guide for Healthcare Professionals (British Medical Association Publications Unit, London, 2003) 16-18 and 20.

${ }^{123}$ See British Medical Association, above n 122, iv and 16-20. For examples of advocacy for mandatory immunisation, see Steven P Shelov "Parents Should Not be Allowed to Opt Out of Vaccinating Their Children" in Mary E Williams (ed) Vaccinations (At Issue Series, Greenhaven Press, San Diego, 2003) <http://galenet.galegroup.com> (last accessed 26 September 2005) Electronic un-paginated version available only; Ross D Silverman and Thomas May "Private Choice Versus Public Health: Religion, Morality, and Childhood Vaccination Law" (2001) 1 Margins 505; Sarah Boseley "Cubans Tell NHS the Secret of £7 a Head Healthcare" (2 October 2000) The Guardian <http://www.guardian.co.uk> (last accessed 20 September 2005); Mountain State Centers for Independent Living "Support Mandatory Immunizations!" $<$ http://www.mtstcil.org > (last accessed 15 September 2005). 
This section outlines why mandatory immunisation is thought to be so problematic, and why it continues to be difficult to argue that the interest of the State in controlling preventable disease outweighs the interest of individuals in being free to refuse immunisation.

\section{A The Right to Refuse Immunisation?}

However tempting it is to conceptualise immunisation as a public endeavour, it is performed upon individuals who must, as individuals, bear its consequences. In Western democracies, there exists a fundamental societal expectation that the right of individuals to behave as autonomous agents will be respected by the State. ${ }^{124}$ This expectation has been strengthened by the enactment of constitutional statutes specifically directed to the protection of individual human rights and freedoms. ${ }^{125}$ Because mandatory immunisation would deny individuals the ability to decide whether or not the personal consequences of immunisation were acceptable to them, it could be seen as undermining the State's general commitment to respect their autonomy. In more concrete terms, our specific human rights commitments can be read as giving rise to a constitutional right to refuse immunisation.

First and foremost among these commitments is the significance accorded to individuals' bodily integrity. ${ }^{126}$ The sovereignty of individuals over their bodies is defined and recognised in a variety of statutory contexts, most relevantly as the right of informed consent to medical interventions, ${ }^{127}$ and the

\footnotetext{
${ }^{124}$ See Jonathan Boston "Social Justice and the Welfare State" in Jonathan Boston, Paul Dalziel and Susan St John (eds) Redesigning the Welfare State in New Zealand: Problems, Policies, Prospects (Oxford University Press, Auckland, 1999) 20, 20-21. See generally Universal Declaration of Human Rights (10 December 1948) UNGA Resolution 217 A (III).

${ }^{125}$ See for example New Zealand Bill of Rights Act 1990; Human Rights Act 1993; Privacy Act 1993.

${ }^{126}$ See Steve P Calandrillo "Vanishing Vaccinations: Why are So Many Americans Opting Out of Vaccinating Their Children?" (2004) 37 U Mich J L Reform 353, 393-394; Ministry of Health Public Health Legislation Review: A New Public Health Legislative Framework: Discussion 127 Document (Wellington, 1998) 24-25 [Public Health Legislation Review].

${ }^{127}$ Health and Disability Commissioner (Code of Health and Disability Services Consumers' Rights) Regulations 1996, 1st sch, cl 2 Right 7(1). See generally Health and Disability Commissioner Act 1994; Privacy Act 1993; Public Health Legislation Review, above n 126, 24; American Academy of Pediatrics (Committee on Bioethics) "Informed Consent, Parental Permission, and Assent in Pediatric Practice" (1995) 95 Pediatrics 314.
} 
right to refuse medical treatment. ${ }^{128}$ The former, which "has been the gold standard in the ethical practice of medical care since World War II", ${ }^{129}$ places more stringent demands upon the State than the latter because it prohibits a health professional from proceeding unless consent to their involvement is obtained, rather than if consent is refused. Although it is not clear that immunisation can be considered a 'treatment' (given that it is administered to healthy children), it is undoubtedly an 'intervention', meaning that New Zealanders have a right not only to refuse immunisation but to expect that it will not be administered in the absence of prior informed consent.

A 'right' to refuse immunisation does not have to be constructed by reference to bodily integrity, however. For example, a mandatory immunisation law would arguably undermine protected rights to freedom of religion, culture and belief, given that some people regard immunisation as incompatible with their religious or cultural convictions. ${ }^{130}$ Freedom to manifest religion in practice "extends to bringing up and educating children in that religion until such time as their children are able to exercise their own freedom of religion". ${ }^{131}$ Even if a child was apparently oblivious to the implications of an immunisation requirement, it could be seen to undermine the parents' ability to manifest their beliefs, representing a "clear loss of personal freedom" for the family as a whole. $^{132}$

Rights not to be deprived of life and/or not to be subjected to medical or scientific experimentation are sometimes invoked as underpinning a right to

\footnotetext{
${ }^{128}$ New Zealand Bill of Rights Act 1990, s 11. See generally American Academy of Pediatrics (Committee of Bioethics), above n 127, 315; Public Health Legislation Review, above n 126, 24.

${ }^{129}$ Barbara Loe Fisher "Parents Should be Allowed to Opt Out of Vaccinating Their Children" in Mary E Williams (ed) Vaccinations (At Issue Series, Greenhaven Press, San Diego, 2003) $<$ http://galenet.galegroup.com> (last accessed 26 September 2005) Electronic un-paginated version available only. See Ministry of Health Consent in Child and Youth Health: Information for Practitioners (Wellington, 1998) 2 [Consent in Child and Youth Health]; Ministry of Health Immunisation Handbook 2002 (Wellington, 2002) 32 [Immunisation Handbook 2002].

${ }_{130}^{13}$ See New Zealand Bill of Rights Act 1990, ss 13, 15 and 20. See VI B 3 Drawing the line.

${ }^{131} \operatorname{Re} J$ (an infant): $B$ and $B v D-G$ of Social Welfare [1996] 2 NZLR 134, 145 (CA) Gault J for the Court. See Convention on the Rights of the Child (20 November 1989) 1577 UNTS 3, art 14.

132 See Chris Feutdner and Edgar K Marcuse "Ethics and Immunization Policy: Promoting Dialogue to Sustain Consensus" (2001) 107 Pediatrics 1158, 1163.
} 
refuse immunisation. ${ }^{133}$ However, a mandatory immunisation law could only be seen to infringe these rights if it was accepted that the risks of immunisation are either grossly underestimated or actively understated by those involved in the development of immunisation policy.

\section{B The Right to Demand Immunisation?}

Even if it is accepted that individuals have a prima facie 'right' to refuse immunisation, it is important to realise that rights are not guaranteed absolute legal protection in New Zealand. For instance, the rights recognised in the New Zealand Bill of Rights Act 1990 (BORA) are generally subject to limitations that can be "demonstrably justified in a free and democratic society", 134 and the International Covenant on Civil and Political Rights contemplates that freedom of religion may be justifiably limited to protect "public safety, order, health, or morals or the fundamental rights and freedoms of others". 135

In a case involving Jehovah's Witness parents who refused life-saving blood transfusions for their child, our Court of Appeal emphasised that the "scope of one right is not to be taken as so broad as to impinge upon and limit others". ${ }^{136}$ In consideration of the right of children not to be deprived of life, the rights of those parents to freedom of religion and to refuse medical treatment were defined to "exclude doing or omitting anything likely to place at risk the life, health or welfare of their children."137

\footnotetext{
${ }^{133}$ See for example Loe Fisher, above n 129; Barbara Loe Fisher (National Vaccine Information Center) "The Moral Right to Conscientious, Personal Belief or Philosophical Exemption to Mandatory Vaccination Laws" (1997) <http://www.909shot.com> (last accessed 26 September 2005) Electronic un-paginated version available only; New Zealand Anti-Vivisection Society "Vaccinations: General - The Conspiracy" <http://www.health.org.nz/artltitle.html> (last accessed 24 September 2005) Electronic un-paginated version available only.

${ }^{134}$ New Zealand Bill of Rights Act 1990, s 5.

135 International Covenant on Civil and Political Rights (19 December 1966) 999 UNTS 171, art 18(3) (emphasis added). See Re $J$ (an infant): $B$ and $B v D-G$ of Social Welfare, above n 131, 145 Gault $J$ for the Court. See further Daniel A Salmon "Mandatory Immunization Laws and the Role of Medical, Religious and Philosophical Exemptions" (Unpublished commentary, John Hopkins Bloomberg School of Public Health, 2003) 2, emphasising that mandatory immunisation is not considered to "violate the First Amendment right to free exercise of religion" in the United States. ${ }_{137}^{136} \operatorname{Re} J$ (an infant): B and B v D-G of Social Welfare, above $\mathrm{n} 131,146$ Gault J for the Court.

${ }^{137} \operatorname{Re} J$ (an infant): B and B v D-G of Social Welfare, above n 131, 146 Gault J for the Court.
} 
It may be possible not only to deconstruct a right to refuse immunisation, but to construct in its place a right to demand that immunisation is implemented by the State. While there is no specific legal right to receive immunisation, every New Zealander has a right to the highest attainable standard of health. ${ }^{138}$ This is normally subject to the right to refuse medical treatment and does not give rise to a corresponding obligation upon individuals to be healthy. However, the right to health can be considered to obligate, first, the government to provide the necessary conditions for its fulfilment, ${ }^{139}$ and, secondly, other individuals not to hamper its exercise.

This has two important implications in the immunisation context. While immunisation is not directly analogous to blood transfusion because it is almost always a preventive rather than a 'life-saving' measure, ${ }^{140}$ it is arguable that withholding immunisation from a child denies them the opportunity to attain a high standard of health. ${ }^{141}$ More broadly, it can be argued that a refusal to participate in immunisation is essentially a selfish decision that undermines the collective right of others to improve the overall standard of health of the community. ${ }^{142}$ This can also be conceptualised as a right of future generations to be free from the threat of preventable diseases. ${ }^{143}$

\footnotetext{
${ }^{138}$ International Covenant on Economic, Social and Cultural Rights (19 December 1966) 993 UNTS 3, art 12.

${ }^{139}$ International Covenant on Economic, Social and Cultural Rights (19 December 1966) 993 UNTS 3, art 12(2)(c) states that steps to be taken by State parties to implement the right to health include those necessary for the "prevention, treatment and control of epidemic ... and other diseases".

${ }^{140}$ See Kath O'Donnell "Re C (Welfare of Child: Immunisation): Room to Refuse? Immunisation, Welfare and the Role of Parental Decision-Making" (2004) 16 C Fam 213 Electronic unpaginated version available only, footnote 6 and accompanying text.

${ }^{441}$ See Ministry of Health (National Health Committee) Review of the Wisdom and Fairness of the Health Funding Authority Strategy for the Immunisation of 'Hard to Reach' Children (Wellington, 1999) 30; P Bradley "Should Childhood Immunisation Be Compulsory?" (1999) 25 JME 330, 333; The Health and Disability Commissioner "Informed Choice and the Rights of Children" (10 February 2000) <http://www.hdc.org.nz> (last accessed 26 September 2005).

${ }_{142}$ See Silverman and May, above n 123, 520-521; Philippe Beutels "On Mandatory Vaccination" <http://www.bmj.bmjjournals.com> (last accessed 24 September 2005) Rapid Response Weblog; Bradley, above n 141, 332-333; Felicity Lawrence "The Battle Over Immunisation" (10 August 2001) The Guardian <http://www.guardian.co.uk> (last accessed 26 September 2005); Alan R Hinman and others "Childhood Immunisation: Laws that Work" (2002) 30 JLME 122, 126.

${ }^{143}$ See United States Department of Health and Human Services (Centers for Disease Control and Prevention) "For Parents: Why Immunize?" <http://www.cdc.gov> (last accessed 26 September 2005); Bradley, above n 141, 332-333.
} 
As Richardson $\mathrm{J}$ (as he then was) observed in $R v$ Jefferies: ${ }^{144}$

Individuals are not isolates. They flourish in their relationships with others. All rights are constrained by duties to other individuals and to the community. Individual freedom and community responsibility are opposite sides of the same coin, not the antithesis of each other. The Bill of Rights should not be approached on the premise that the state and those exercising powers on its behalf are enemies of the public good.

Leaving aside the argument that the State is not acting as an 'enemy' of the public good or of individuals who it compels to be immunised, since immunisation serves the interests of both, some commentators have described immunisation as a "public duty" to current and future generations. ${ }^{145}$ In this respect, it is noted that although successfully immunised individuals (unlike everyone else) are not physically endangered by others' refusal of immunisation, they can still be "harmed by the cost of medical care for those who choose not to immunize their children and whose children then contract vaccine-preventable disease." 146 Some have gone so far as to suggest that immunisation constitutes a pre-requisite to membership of a responsible society, by analogy with accepted obligations to contribute to (for example, by paying tax) or not to detract from (for example, by respecting traffic laws drafted to avoid accidents) the public good. $^{147}$

\section{$1 \quad$ The numbers game}

The small number of New Zealand parents opposed to immunisation weighs in on both sides of the mandatory immunisation debate. On one hand, the overwhelming degree of support for immunisation in principle lends weight to

\footnotetext{
${ }^{144} R v$ Jefferies [1994] 1 NZLR 290, 303 (CA) Richardson J.

${ }^{145}$ See for example E Vermeersch "Individual Rights Versus Societal Duties" (1999) 17 Vaccine S14; Beutels, above $\mathrm{n} \mathrm{142;}$ but see New Zealand Health Trust Public Health Legislation Discussion Paper (submission to Ministry of Health, 2003) 5.

146 Douglas S Diekema and American Academy of Pediatrics (Committee on Bioethics) "Responding to Parental Refusals of Immunization of Children" (2005) 115 Pediatrics 1428, 1429.

${ }^{147}$ See United States Department of Health and Human Services (National Vaccine Program Office) "Immunization Laws" <http://www.cdc.gov> (last accessed 26 September 2005); Diekema, above n 146, 1429; Hinman and others, above n 142, 126; United States Department of Health and Human Services (Centers for Disease Control and Prevention) "For Parents: Why Immunize?" < http://www.cdc.gov> (last accessed 26 September 2005); Don Brash MP "Brash Responds to Maharey" (31 January 2005) Media Release. See generally Lawrence M Mead Beyond Entitlement: The Social Obligations of Citizenship (Macmillan, New York, 1986) 12.
} 
arguments that any concession to the anti-immunisation lobby demonstrates an irrational willingness to tolerate harm to all to avoid harm to a few. On the other hand, any suggestion that State-mandated immunisation is a reasonable corollary of citizenship deserves close scrutiny, simply because there are people who would otherwise be considered responsible citizens that do not share this view.

\section{Practical Considerations}

Even if mandatory immunisation was thought to be compatible with New Zealand's human rights commitments, translating it into an effective and sustainable legal framework would be a daunting task. ${ }^{148}$ While in principle our Parliament's power may be unlimited, in practice it is constrained by the need for law to be palatable to the public that elects the enacting government and crucially - its successors. It may be tempting for policy-makers "faced with what seems to be an irrational decision by parents to refuse vaccination"149 to trust that those whose decisions are overridden will grow to accept that the State has acted wisely on their behalf. However, Calandrillo has warned that "using absolute mandates to increase immunization levels is probably not a wise social policy, and could produce a serious backlash." 150

Legislative removal of freedom of choice would, hopefully, be based on an assumption that rational, fully informed citizens would choose immunisation but that allowing diseases to persist uncontrolled while that realisation slowly dawns upon everyone is not acceptable. Unfortunately, it might convey the opposite impression, in that people would reason that there would have been no need to remove freedom of choice unless rational people might well exercise that freedom against immunisation. "The more health officials and doctors force, rather than persuade, people to do what they want them to do, the more fearful and hostile the people will become."

\footnotetext{
${ }^{148}$ See British Medical Association, above n 122, 16; United Kingdom Department of Health Immunisation Against Infectious Disease (London, 1996) Foreword; Feutdner and Marcuse, above n 132, 1163. Compare Hinman and others, above n 142, 123.

${ }^{149}$ McIntyre, Williams and Leask, above n 122, 150.

${ }^{150}$ Calandrillo, above n 126, 437.

${ }^{151}$ Loe Fisher, above n 129.
} 
At present, fully immunising children at birth is not practicable: rather, there has to be a way to reach them at each of the six ages at which vaccinations are ideally administered. As Bradley has suggested, if parents are excluded from one vaccination decision, the likelihood of their compliance with subsequent scheduled immunisation - and other health - interventions may be decreased. ${ }^{152}$ The promotional resources currently devoted to overcoming parental inertia would not necessarily be saved by a mandatory immunisation law, but might be required to maintain support for the law (both across generations, and over the developmental span of children) by continually highlighting its democratic foundation and ultimate objectives.

\section{$1 \quad$ How do you enforce an immunisation law?}

To successfully overcome parental opposition, it would have to be more onerous to defy or ignore an immunisation law than to comply with it. Yet even if immunisation was regarded as a societal duty, any law would be intended to enhance, not diminish, people's ability to live free, productive lives. It is difficult to conceptualise a sanction that would be appropriately serious without being unduly punitive. For example, in Belgium, children can be temporarily removed from their parents' guardianship if the parents refuse the polio vaccine. ${ }^{153}$ Apart from being likely to attract vociferous public opposition if proposed today, the disruption of the family environment seems needlessly heavy-handed. As another example, it has been suggested that "parents who chose not to immunise their children should pay the full costs of any health care resulting from that decision." ${ }^{154}$ Like proposals to withhold some or all benefit payments from beneficiaries, ${ }^{155}$ this kind of monetary sanction would probably have the flow-on effect of punishing the very children it was intended to protect.

\footnotetext{
${ }^{152}$ Bradley, above n 141, 331.

153 Beutels, above n 142.

${ }^{154}$ Department of Social Welfare Towards a Code of Social and Family Responsibility: The Response Report (Wellington, 1998) 47.

${ }^{155}$ See VII Immunisation and Beneficiaries.
} 
Most countries that have adopted some form of coercive immunisation have linked the implementation and enforcement of immunisation laws to the education of their children. In the United States, for example, every state has legislation that prevents schools from accepting un-immunised children unless parents have successfully navigated a statutory exemption process. ${ }^{156}$ Further, in most Western countries (including New Zealand), un-immunised children can be excluded from school upon an outbreak of disease. ${ }^{157}$ This kind of provision is generally designed to protect children rather than to raise coverage levels or punish un-immunised children, but rests upon the same premise: that the immunisation status of children is a permissible basis upon which to exclude them from school.

School immunisation laws have received some heavy criticism. They can constitute "implicit (inequitable) coercion" for those actively opposed to immunisation, by setting up an inescapable conflict between the interests of parent and child. ${ }^{158}$ Further, any eventual deterrent effect would come at the expense of those children - already vulnerable by being un-immunised - whose parents did not have the means or the motivation to make safe and effective home-schooling arrangements, and who might therefore experience substantial disruption of their right to education. ${ }^{159}$ The inability of children to insist on the fulfilment of this fundamental right is currently reflected by a statutory provision

\footnotetext{
${ }^{156}$ See Calandrillo, above n 126, 355-357; Salmon, above n 135, 1; Ross D Silverman "No More Kidding Around: Restructuring Non-Medical Childhood Immunization Exemptions to Ensure Public Health Protection" (2003) 12 Ann Health L 277, 280-284; M Craig Smith "A Bad Reaction: A Look at the Arkansas General Assembly's Response to McCarthy v Boozman and Boone v Boozman" (2005) 58 Ark L Rev 251, 251.

${ }^{157}$ See National Network for Immunization Information "Common Questions about School Immunization Laws" <http://www.immunizationinfo.org> (last accessed 24 September 2005); McIntyre, Williams and Leask, above n 122, 150; British Medical Association, above n 122, 17 18. See III B 1 Health (Immunisation) Regulations 1995.

${ }_{158}^{158}$ Beutels, above n 142 .

${ }^{159}$ See Department of Social Welfare, above n 154, 47; New Zealand Health Trust, above n 145, 20; Methodist Mission (South Island) Social Comment from the Mission: Towards a Code of Social and Family Responsibility (submission to Department of Social Welfare, 1998) Electronic un-paginated version available only 'Issue 3: Keeping Our Children Healthy'. For the right of children to an education, see Education Act 1989, s 3; Convention on the Rights of the Child (20 November 1989) 1577 UNTS 3, art 28(1).
} 
making school attendance compulsory, ${ }^{160}$ the protective effect of which would be undermined by any law that resulted in the exclusion of school-age children for significant periods.

Yet it is precisely the mandatory nature of school attendance that makes new entrants an ideal target for immunisation initiatives. There is simply no other occasion when so many children are simultaneously within the reach of health authorities. Further, the fact that school attendance is mandatory reflects its stability as a social policy. A United States expert has emphasised that "school laws establish a system for immunization, a system that works year in and year out, regardless of political interest, media coverage, changing budget situations, and the absence of vaccine-preventable disease outbreaks to spur interest". ${ }^{161}$

The government's obligation to educate children can be seen as a corollary of its right to demand that those children fulfil their potential as citizens by becoming educated. One un-immunised child poses a demonstrable short-term risk to others in their class, who also have a right to education. More crucially, perhaps, a child is more likely to suffer a compromised or terminated education as the result of contracting a vaccine-preventable disease than from being excluded until their parents comply with immunisation laws. School-entry requirements can, therefore, be seen as representing an appropriate balance between the interests of children in education and the rights and obligations of the government in respect of the provision of that education. ${ }^{162}$

\section{$3 \quad$ Emergencies}

The one scenario in which the Ministry of Health considers that mandatory immunisation might be justified is as an urgent measure to combat an "extreme threat" of vaccine-preventable disease. ${ }^{163}$ The default position, whereby

\footnotetext{
${ }^{160}$ Education Act 1989, s 20.

${ }^{161}$ Dr Walter Orenstein, Director of the National Immunization Program, Centers for Disease Control and Prevention, quoted in Salmon, above n 135, 1.

${ }_{162}$ See Hinman and others, above n 142, 126.

${ }^{163}$ Ministry of Health Public Health Legislation: Promoting Public Health, Preventing Ill Health and Managing Communicable Diseases: Discussion Paper (Wellington, 2002) 33 [Public Health Discussion Paper]. See generally Calandrillo, above n 126, 384; Jacobson v Massachusetts (1905)
} 
providers risk civil and criminal liability for proceeding in the absence of prior informed consent, ${ }^{164}$ could be altered by prospectively legitimating vaccination in defined 'emergency' circumstances - of those people for whom "efforts made to obtain consent have failed or obtaining consent is not practicable in the circumstances." 165

Although this prospect might seem even more alarming than a universal immunisation requirement, given that normal procedural safeguards could potentially be dispensed with, there are several reasons why it is likely to be viewed as less oppressive than a 'peacetime' law. First, although still a preventive measure, both the connection between action (vaccination) and consequence (survival) and the comparison between risk of vaccine and risk of disease are easier for individuals to draw if a disease is wreaking present havoc. Secondly, the Ministry's focus is squarely on terrorist-introduced disease, to the point where no reference was made to a naturally occurring epidemic in the most recent discussion paper. ${ }^{166}$ People are more likely to engage with the 'selfless' benefits of immunisation if they can conceptualise it as a war against a visible opponent - terrorists, disease, or both - rather than a long-term guerrilla campaign with no obvious target. Finally, emergency vaccinations would be administered to adults as well as, or possibly instead of, children, negating some common reservations about immunisation programmes (such as that the State relies upon children's powerlessness to implement immunisation for its own ends).

197 US 11 (where the State of Massachusetts' police power to protect the public's health was held by the Supreme Court to include the right to require that all citizens of the city of Cambridge receive a smallpox vaccination during an outbreak).

${ }^{164}$ See Immunisation Handbook 2002, above n 129, 32.

${ }^{165}$ Public Health Discussion Paper, above n 163, 35.

${ }^{166}$ See Public Health Discussion Paper, above n 163, 35. 
Accepting that the power to make decisions about immunisation should generally rest with individuals, rather than the State, does not mean that the State has to withdraw from the decision-making process altogether. While any law that attempts to strike a balance between individual freedom and public good must not have the effect of removing individuals' ability to make a decision, it may legitimately prevent them from not making a decision. Indeed, given the everpresent danger of confusion and misinformation in the immunisation context, it is not clear that a requirement merely to communicate a decision will be sufficient to eliminate passive non-immunisation. Further legislative intrusion may be warranted to ensure that only those who are considered to be 'actively' opposed to immunisation abstain from the national programme.

We have seen that the New Zealand system is effectively an 'opt-in' one. The importance of making a choice is stressed by the State, and immunisation is promoted as a safe and 'normal' option. However, the default position is that providers should not proceed with immunisation in the absence of express consent. Further, there are no sanctions for unreasonable failure to give this consent, which may mean in practice that it appears easier in the short term to ignore or refuse immunisation than to accept it.

There is another way. An 'opt-out' or 'exemption' system - of which the United States is the most famous example - creates a legal presumption in favour of immunisation, at the point of enrolment in primary school, which requires some degree of individual effort to displace. There is enormous scope for variation in the structure and stringency of an exemption scheme; a relatively weak version was flagged in the recent public health discussion papers. ${ }^{167}$ In New Zealand, given that 'informed consent' is the touchstone for opting into immunisation, it seems logical to consider whether 'informed refusal' might be required in order to opt out of immunisation. ${ }^{168}$

\footnotetext{
${ }^{167}$ See III D 2 Public health reform.

${ }^{168}$ See Ross D Silverman "No More Kidding Around: Restructuring Non-Medical Childhood Immunization Exemptions to Ensure Public Health Protection" (2003) 12 Ann Health L 277, 294.
} 
Consent to medical interventions is regarded as an ongoing process rather than an isolated event. The process, as embodied in the Code of Health and Disability Consumer's Rights (Code), ${ }^{169}$ is directed towards ensuring that consumers make decisions that are voluntary, informed and competent. In practice, it: ${ }^{170}$

$[\mathrm{N}]$ ecessarily involves effective communication in a form, language, and manner that enables the consumer to understand the information provided. It also involves provision of all necessary information, including information about options, risks, side-effects, benefits and costs.

A key point to emphasise in the immunisation context is that an informed decision does not mean an objectively 'correct' decision, or even one that anyone else agrees with, but rather a decision made freely on the basis of appropriate information. ${ }^{171}$ Unless we are prepared to assert that it is not possible for an informed and competent consumer to refuse immunisation (in which case any 'right' of informed refusal would be hollow, and there seems no reason not to seriously consider mandatory immunisation), caution is required in impliedly equating an 'informed' decision to an acceptance of immunisation.

\footnotetext{
${ }^{169}$ Health and Disability Commissioner (Code of Health and Disability Services Consumers' Rights) Regulations 1996 (particularly 1st sch, cl 2 Rights 5, 6 and 7).

${ }_{170}$ Aphra Green "Immunisation in New Zealand: Patient Autonomy, Informed Consent, and the Code of Rights" (2002) 1 NZ Students' Law Jnl 203, 204. See Ministry of Health Immunisation Handbook 2002 (Wellington, 2002) 32-35 [Immunisation Handbook 2002]; United Kingdom Department of Health "Draft Chapter 3 Consent" in Immunisation Against Infectious Disease (Draft revised version, London, 2004) 2; The Health and Disability Commissioner "What Do I Need to Know about 'Informed Consent'?" (30 June 2005) <http://www.hdc.org.nz> (last accessed 26 September 2005).

${ }_{171}$ See American Academy of Pediatrics (Committee on Bioethics) "Informed Consent, Parental Permission, and Assent in Pediatric Practice" (1995) 95 Pediatrics 314, 314-315; The Health and Disability Commissioner, above n 170.
} 


\section{$1 \quad$ Children and consent to medical interventions}

The paradigm of informed consent does not translate perfectly into the immunisation context, for the simple reason that most immunisation 'consumers' are young children. ${ }^{172}$ On the assumption that the inchoate developmental status of children denies them the capacity to consent to medical interventions, the Care of Children Act 2004 authorises a legal guardian to consent on their behalf. ${ }^{173}$ This general authorisation may be displaced in four broad circumstances: ${ }^{174}$

(a) where the treatment has been ordered by a court; (b) where the parents have abandoned the child; (c) where there is a life-threatening emergency; and (d) where the child is old enough to have sufficient understanding and intelligence to be able to provide a valid consent.

Any of these could conceivably enable immunisation to proceed. However, the fourth is the only one potentially enabling a recipient - in particular, the 11 year olds who receive the last scheduled immunisation - to consent on their own behalf. ${ }^{175}$ Although the current handbook for providers does contemplate this possibility, ${ }^{176}$ in practice New Zealand providers "appear to have presumed an obligation to obtain parental consent if a child is under 16", 177 meaning that 'informed consent' to childhood immunisations is always given by proxy. ${ }^{178}$

This does not mean that children are irrelevant, except as physical participants, to the immunisation process. The inability of children to make 'informed' decisions does not affect their right to "have their views considered in

\footnotetext{
172 See American Academy of Pediatrics (Committee on Bioethics), above n 171, 314.

${ }^{173}$ Care of Children Act 2004, s 36(3).

174 John Dewar Law and the Family (Butterworths, London, 1989) 73.

${ }^{175}$ See generally Gillick $v$ West Norfolk Health Authority [1985] 3 All ER 402, 422-424 (HL(E)) Lord Scarman. It is assumed for the purposes of this paper that children four years old and younger would not be considered 'Gillick-competent' in respect of immunisation.

${ }^{176}$ See Immunisation Handbook 2002, above n 170, 278.

177 Immunisation Handbook 2002, above n 170, 34; see Green, above n 170, 204-205.

${ }^{178}$ See American Academy of Pediatrics (Committee on Bioethics), above n 171, 315.
} 
matters that affect them", ${ }^{179}$ and health professionals have an obligation to ensure that children are informed according to their ability and level of understanding. ${ }^{180}$

2 The 'right' of parents to make immunisation decisions

Parents may be free to become martyrs themselves. But it does not follow that they are free, in identical circumstances, to make martyrs of their children before they have reached the age of full and legal discretion ... ${ }^{181}$

It is often assumed that parents or caregivers are not only ideally placed to make, but have a right to make, immunisation decisions for their children. ${ }^{182}$ In fact, the parental decision-making role now tends to be characterised reflecting a shift towards consideration of children as valued citizens, not mere extensions of their parents - more as a "responsibility or power" than a right. ${ }^{183}$ Despite consensus that the raison d'être of this 'power' is the best interests of the child, ${ }^{184}$ there is disagreement over both the meaning and content of 'best interests, 185 and how tightly parental decision-making is constrained by reference to it. On one view, parents have no power to make decisions that are not in their child's best interests. In reality, this is not enforced (or enforceable)

\footnotetext{
${ }^{179}$ Ministry of Social Development New Zealand's Agenda for Children: Making Life Better for Children (Wellington, 2002) 11.

${ }^{180}$ Green, above $\mathrm{n} 170,204$. See Ministry of Health Consent in Child and Youth Health: Information for Practitioners (Wellington, 1998) 54; American Academy of Pediatrics (Committee on Bioethics), above n 171, 315.

${ }^{181}$ Prince v Massachusetts (1944) 321 US 158, 170 Rutledge J: quoted in Silverman, above n 168, 281.

${ }^{182}$ See American Academy of Pediatrics (Committee on Bioethics), above n 171, 315; Kath O'Donnell "Re C (Welfare of Child: Immunisation): Room to Refuse? Immunisation, Welfare and the Role of Parental Decision-Making" (2004) 16 C Fam 213 Electronic un-paginated version available only 'Parental Decision Making'; New Zealand Health Trust, above n 145, 19.

${ }^{183}$ O'Donnell, above n 182, 'Parental Decision Making'. See British Medical Association Childhood Immunisation: A Guide for Healthcare Professionals (British Medical Association Publications Unit, London, 2003) 13-14; Barbara Loe Fisher (National Vaccine Information Center) "The Moral Right to Conscientious, Personal Belief or Philosophical Exemption to Mandatory Vaccination Laws" (1997) <http://www.909shot.com> (last accessed 26 September 2005) Electronic un-paginated version available only; Gillick v West Norfolk Health Authority, above n 175, 420-421 Lord Scarman; Ministry of Social Development, above n 179, 11.

${ }^{184}$ See Dewar, above n 174, 68; Ross D Silverman and Thomas May "Private Choice Versus Public Health: Religion, Morality, and Childhood Vaccination Law" (2001) 1 Margins 505, 518; British Medical Association, above n 183, 14. See generally Care of Children Act 2004, s 4; Convention on the Rights of the Child (20 November 1989) 1577 UNTS 3, art 3(1).

${ }^{185}$ See for example O'Donnell, above n 182, 'Welfare and Best Interests' and 'Welfare and Medical Best Interests'.
} 
beyond the prohibition of parental abuse and neglect, ${ }^{186}$ and there is no consensus that refusal of non-lifesaving immunisation constitutes legal neglect. ${ }^{187}$ On another view, shared by the majority of commentators, children's best interests are inextricably linked with the ability of those with primary responsibility for them to make decisions about their upbringing. ${ }^{188}$ However: ${ }^{89}$

This account can be criticised for its failure to acknowledge that parents' interests may conflict with those of the child and that parents may - perhaps unconsciously define their child's best interests in terms of their own interests, to the detriment of the child.

Feudtner and Marcuse have identified a general tension between "the duties that our society entrusts to parents to promote the health and safety of their children and assigns to governmental and other agencies to safeguard the welfare of children." 190 That the State has decided that the best interests of children, both as a group and (almost always) individually, lie in receiving immunisation renders parental refusal of immunisation inherently problematic. The State's bias towards immunisation is demonstrated where disagreement between caregivers leads to applications to the courts and an increasingly acrimonious series of hearings; even in the face of fervent opposition from the primary caregiver, immunisation has generally been ordered to proceed. ${ }^{191}$

\footnotetext{
${ }^{186}$ See British Medical Association, above n 183, 13-14; Silverman and May, above n 184, $518-$ 519; Peter McIntyre, Alison Williams and Julie Leask "Refusal of Parents to Vaccinate: Dereliction of Duty or Legitimate Personal Choice?" (2003) 178 MJA 150 (editorial) 150.

${ }^{187}$ British Medical Association, above n 183, 14. But see Don Brash MP "Brash Responds to Maharey" (31 January 2005) Media Release.

${ }^{188}$ See O'Donnell, above n 182, 'Parental Decision Making'; Silverman and May, above n 184, 518; American Academy of Pediatrics (Committee on Bioethics), above n 171, 315; McIntyre, Williams and Leask, above n 186, 150; Loe Fisher, above n 183.

189 O'Donnell, above n 182, 'Parental Decision Making'.

${ }^{190}$ Chris Feutdner and Edgar K Marcuse "Ethics and Immunization Policy: Promoting Dialogue to Sustain Consensus" (2001) 107 Pediatrics 1158, 1160. See Silverman and May, above n 184, 509 (footnote 21 in original) and 518-519; John Angus "The Code of Social and Family Responsibility as a Family Policy Initiative" in Judith A Davey (ed) Another New Zealand Experiment: A Code of Social and Family Responsibility (Institute of Policy Studies, Wellington, 2000) 137, 147.

${ }^{191}$ See generally O'Donnell, above n 182. See Re C and F (children) (immunisation) [2003] All ER (D) 179 (HC); Re C (Welfare of Child: Immunisation) [2003] EWCA Civ 1148; Rogal v Smith [2003] NZFLR 75 (FC); Clare Dyer "Judge Overrules Mothers' Objections to MMR Vaccine" (2003) 326 BMJ 1351; Clare Dyer "Mothers Lose Anti-MMR Battle" (31 July 2003) The Guardian <http://www.guardian.co.uk> (last accessed 26 September 2005); James Meikle "Court Win for Fathers in MMR Jabs Fight" (14 June 2003) The Guardian $<$ http://www.guardian.co.uk> (last accessed 26 September 2005).
} 
If we accept that immunisation decisions should be made by reference to a child's best interests, and that those 'interests' (notoriously difficult to define) include but are not limited to medical best interests, ${ }^{192}$ the current legal framework is not entirely satisfactory. If parents are united in refusing immunisation, there is no way of ensuring they have not made a demonstrably wrong decision on medical grounds, or that their own broader interests have not (consciously or otherwise) dominated to the detriment of their child. If parents disagree, by contrast, the important benefits in having immunisation decisions made by a child's primary caregivers - who probably know and care the most about that child - seem in danger of being swamped by the courts' focus on medical best interests. ${ }^{193}$

The balance between the various parties with legitimate interests in the immunisation of a child (which, beyond child, family and State, may also include doctors with professional duties of care to the child) is a sensitive one. ${ }^{194}$ However, the likelihood of a result that prioritises parental decision-making while keeping the best interests of the child in focus may be enhanced by the introduction of an exemption scheme. By clearly articulating the various interests in play, legislation could raise parental awareness that immunisation decisions have implications beyond the immediate family environment. More practically, legislation could limit parents' ability to refuse immunisation to circumstances where the State is satisfied that medical best interests have been adequately considered and that refusal is unlikely to be clearly against the overall best interests of a child. ${ }^{195}$

\footnotetext{
${ }^{192}$ See generally O'Donnell, above n 182, 'Welfare and Best Interests' and 'Welfare and Medical Best Interests'.

${ }^{193}$ See O'Donnell, above n 182, 'Welfare and Medical Best Interests' and 'The Court of Appeal Judgments'.

${ }_{194}$ See American Academy of Pediatrics (Committee on Bioethics), above n 171, 315; Feudtner and Marcuse, above n 190, 1159; New Zealand Health Trust, above n 145, 19.

${ }^{195}$ See VI B Statutory Exemptions and the Illusion of Choice.
} 
Given that there are valid reservations about resolving disputes over routine childhood immunisation through the courts, ${ }^{196}$ it may be that some form of alternative dispute resolution should be facilitated by legislation introducing an exemption scheme. Mediation, for example, could be relatively cheap and accessible, keep bad feeling to a minimum and focus on persuasion rather than coercion. If the exposition of all points of view (including, potentially, a Stateappointed representative of the child) failed to secure consensus, the situation could proceed to binding arbitration.

\section{THE TROUBLE WITH 'INFORMED' DECISIONS}

\section{A The State Taking Sides}

If the State imposes an informed refusal requirement, it must ensure that the preconditions for making an informed decision are present. ${ }^{197}$ For this to happen, parents need medical information that is "objective, balanced and politics-free", 198 in order to be "as fully informed as possible, within the available information and [their] own limitations". ${ }^{199}$ This can be problematic in practice, not only because the State has to monitor the information it provides to ensure that its vested interest in immunisation does not overwhelm the decisionmaking process, but because it must also grapple with the information available to parents from non-official sources.

\section{$1 \quad$ Providing information}

The Ministry of Health has not attempted to maintain a rigid distinction between its responsibility to promote immunisation and its responsibility to facilitate informed decisions. This is defensible, notwithstanding concerns that it

\footnotetext{
${ }^{196}$ See generally O’Donnell, above n 182; Clare Dyer "Judge Overrules Mothers' Objections to MMR Vaccine” (2003) 326 BMJ 1351.

197 See Ministry of Health Immunisation Handbook 2002 (Wellington, 2002) 32-33 [Immunisation Handbook 2002].

${ }^{198}$ British Medical Association Childhood Immunisation: A Guide for Healthcare Professionals (British Medical Association Publications Unit, London, 2003) 15. See New Zealand Health Trust Public Health Legislation Discussion Paper (submission to Ministry of Health, 2003) 6.

199 The Health and Disability Commissioner "What Do I Need to Know about 'Informed Consent'?" (30 June 2005) <http://www.hdc.org.nz> (last accessed 26 September 2005).
} 
gives rise to an irreconcilable conflict of interest, ${ }^{200}$ since our official policy may be seen as reflecting an informed societal decision to accept immunisation. However, care must be taken to ensure that the Ministry's motive in providing immunisation information is, and is seen to be, the facilitation of free decisions (the outcomes of which will receive unconditional official recognition) rather than the mere ticking of a procedural box in pursuit of the end of universal immunisation.

Face-to-face interactions between health professionals and consumers are undoubtedly the most important in terms of the facilitation of immunisation decisions, and the only time the State has an effective monopoly as against the anti-immunisation lobby. Notwithstanding fairly detailed Ministry directives, ${ }^{201}$ Aphra Green has noted that information given to parents during oral consultations "is at the complete discretion of the provider, who will often place their own emphases on different aspects of the benefits, costs or otherwise of immunisation."202 The trust generally placed in doctors by parents, who may rely exclusively upon them to 'translate' scientific arguments, provides an ideal vehicle for stressing the important benefits of immunisation and combating misperceptions about it. ${ }^{203}$ However, it also requires policy-makers to tread carefully in making demands upon providers that might be unrealistic (for example, parents with "emotional rather than intellectual" objections to immunisation are unlikely to be swayed by medical argument) $)^{204}$ or require them to play a more aggressive role than their professional obligations would generally envisage. $^{205}$

${ }^{200}$ See New Zealand Health Trust, above n 198, 5-6; New Zealand Anti-Vivisection Society "Vaccinations: General - The Conspiracy" < <ttp://www.health.org.nz/artltitle.html $>$ (last accessed 24 September 2005) Electronic un-paginated version available only,

${ }^{201}$ See Immunisation Handbook 2002, above n 197, 33 and 240-241.

202 Aphra Green "Immunisation in New Zealand: Patient Autonomy, Informed Consent, and the Code of Rights" (2002) 1 NZ Students' Law Jnl 203, 206.

${ }^{203}$ See British Medical Association, above n 198, 18-20. See generally Douglas S Diekema and American Academy of Pediatrics (Committee on Bioethics) "Responding to Parental Refusals of Immunization of Children" (2005) 115 Pediatrics 1428.

${ }^{204}$ Immunisation Handbook 2002, above n 197, 241. See Peter McIntyre, Alison Williams and Julie Leask "Refusal of Parents to Vaccinate: Dereliction of Duty or Legitimate Personal Choice?" (2003) 178 MJA 150 (editorial) 150-151.

${ }^{205}$ See generally Green, above n 202, 207; The Health and Disability Commissioner "Informed Choice - Not a Matter of Negotiation" (9 February 2005) <http://www.hdc.org.nz $>$ (last accessed 26 September 2005); The Immunisation Awareness Society Inc <http://www.ias.org.nz $>$ (last accessed 24 September 2005). 
Outside the doctor's office, 90 per cent of parents in a 2003 survey felt that the standard information that the Ministry provides (a multilingual brochure and more comprehensive booklet, also available electronically) was adequate to enable them to make informed immunisation decisions. ${ }^{206}$ Although this does not of course mean that the information is adequate in objective terms, it is an encouraging figure, especially since there is actually much more Ministrysanctioned information available. For example, the ubiquitous Well Child Handbook provides contact details for the Immunisation Advisory Centre as the "first port of call" for concerned parents. ${ }^{207}$ This Centre, established by the Ministry and based at the University of Auckland, aims to promote awareness of immunisation and to "influence attitudes by the provision of knowledge" to providers and the community. ${ }^{208}$

Much is made of the dependence of parents upon immunisation information provided by health professionals. ${ }^{209}$ On the other hand, officials are becoming increasingly open about the fact that most of the mass of private immunisation information available aims to 'influence attitudes' away from immunisation, ${ }^{210}$ and (more ominously) may not adhere to "good information practices". ${ }^{211}$ The Internet, in particular, is of "great concern" to policy-

\footnotetext{
${ }^{206}$ Ministry of Health "National Immunisation Programme News" (Issue 2, July 2003) $<$ www.moh.govt.nz> (last accessed 20 September 2005).

${ }^{207}$ Ministry of Health Well Child Tamariki Ora Health Book (Revised, Wellington, 2005) 141.

${ }^{208}$ Ministry of Health Progress on Health Outcome Targets 1998 (Wellington, 1998) 80 [Progress on Healti Uutcome Targets]. See Immunisation Advisory Centre $<$ www.immune.org.nz> (last accessed 24 September 2005).

${ }^{203}$ See British Medical Association, above n 198, 18; Ann Robinson "Cracks in Public Confidence" (11 August 2004) The Guardian <http://www.guardian.co.uk> (last accessed 20 September 2005); United States Department of Health and Human Services (National Vaccine Program Office) "Immunization Laws" <http://www.cdc.gov> (last accessed 26 September 2005) 210 See for example American Academy of Pediatrics (Childhood Immunization Support Programme) "Letter from American Academy of Pediatrics President, Carol Berkowitz, MD, FAAP" <www.cispimmunize.org> (last accessed 13 September 2005); United States Department of Health and Human Services (Centers for Disease Control and Prevention) "Six Common Misconceptions about Vaccination and How to Respond to Them" <http://www.cdc.gov> (last accessed 26 September 2005).

${ }^{211}$ World Health Organisation "Vaccine Safety Net" < www.who.int/immunization_safety $>$ (last accessed 13 September 2005).
} 
makers. $^{212}$ Over half of American parents are thought to rely on the Internet for supplementary health information, ${ }^{213}$ notwithstanding that it can be extremely difficult for parents to gauge the trustworthiness of that information. Research has revealed worrying levels of ignorance among New Zealand parents, directly fuelled by anti-immunisation material: for example, one in five parents believe that good hygiene and nutrition can prevent communicable diseases. ${ }^{214}$ There is little point in the State providing objective and balanced immunisation information if private groups that have no such compunction succeed in capturing the decision-making process and triggering an "inappropriate erosion of public confidence". 215

This said, it is unrealistic to imagine that immunisation 'misinformation' could be seriously cracked down upon. The chances of successfully silencing the - mostly international - plethora of anti-immunisation websites are slim indeed. More importantly, the censorship of minority opinions (no matter how deluded or pernicious, in the State's view) is both deeply constitutionally problematic and unlikely, unless carried out with brutal efficiency, to do more than increase the determination of those holding the opinions to get their message across. $^{216}$

What policy-makers can and should do is confront the arguments of the anti-immunisation lobby in an "open and unbiased" way. ${ }^{217}$ It may not be possible or desirable to counter all of these arguments on their own terms (for example, suggestions that the government's sole motivation in providing immunisation is profit), but it is possible to disabuse consumers of the notion that they have stumbled onto secret truths about immunisation that providers are

212 British Medical Association, above n 198, 19. See Steve P Calandrillo "Vanishing Vaccinations: Why are So Many Americans Opting Out of Vaccinating Their Children?" (2004) 37 U Mich J L Reform 353, 359 and 402-403.

${ }^{213}$ British Medical Association, above n 198, 19.

214 Tara Ross "Parents Flock to Infect Kids at "Pox Parties"' (7 August 2005) The Manawatu Standard <http://www.stuff.co.nz> (last accessed 26 September 2005). See generally Diekema, above n 203, 1429.

215 British Medical Association, above n 198, 8.

216 See New Zealand Bill of Rights Act 1990, s 14 (protected right of individuals to freedom of expression). See P Bradley "Should Childhood Immunisation Be Compulsory?" (1999) 25 JME 330,331 .

217 Ann Kempe Immunisation Programs in NZ, USA, Canada, UK and Finland: Lessons for Australia and South Australia (1998 Churchill Fellowship Report, Canberra, 1999) 45. 
unable or unwilling to see. Government-sanctioned organisations overseas have taken proactive approaches to the spectre of misinformation, for example by providing consumers with criteria against which they are encouraged to assess immunisation websites before relying upon their advice. ${ }^{218}$ The United States Centers for Disease Control: ${ }^{219}$

$[R]$ egularly browse the scientific and medical literature and the mass media to assess what the immunisation issues of the moment are and put a communication strategy together and disseminate the information in a timely way before the issue escalates and forces a defensive approach ...

Although the Ministry has taken a positive step by including a section devoted to handling commonly-raised objections to immunisation in the current handbook for providers, ${ }^{220}$ it may be necessary to accept that, given the emotive weight of many anti-immunisation arguments and the relative lack of behavioural constraints upon private agents, more forceful measures are needed. The Immunisation Advisory Centre's ability to “influence attitudes through the provision of knowledge" could be crucially valuable in this regard. ${ }^{221}$

\section{B Statutory Exemptions and the Illusion of Choice}

The concept of a legal framework designed to enforce 'choice' about immunisation is slightly counter-intuitive. In its usual context, the principle of informed consent creates a prohibition on any action unless the consumer agrees. An 'opt-out' system, by contrast, requires parents to immunise their children (which may only require sending them to school, where catch-up vaccinations can be administered) unless they positively refuse. The minimum action that is required of parents in overseas jurisdictions is ticking a refusal box: more

\footnotetext{
${ }^{218}$ See British Medical Association, above n 198, 19; National Network for Immunization Information "Parents: Evaluating Information on the Web" $<$ http://www.immunizationinfo.org $>$ (last accessed 26 September 2005); Vaccine Safety Net <www.who.int/immunization_safety $>$ (last accessed 13 September 2005).

${ }^{219}$ Kempe, above n 217, 45.

${ }^{220}$ Immunisation Handbook 2002, above n 197, ch 19. Compare United States Department of Health and Human Services (Centers for Disease Control and Prevention) "Six Common Misconceptions about Vaccination and How to Respond to Them" < http://www.cdc.gov> (last accessed 26 September 2005).

${ }^{221}$ Progress on Health Outcome Targets, above n 208, 80.
} 
onerous requirements can extend from providing written reasons, to failing to be persuaded by mandatory education sessions, to having to prove that refusal is based on a specific, legislatively sanctioned ground.

Exemption, objection or abstention?

The degree of stigma that would or should attach to un-immunised children and their parents under an exemption scheme would likely relate to the degree of moral pressure imposed by originating legislation. This pressure could be as subtle as the basic terminology used. Although reference is commonly made to "conscientious objections" to immunisation, ${ }^{222}$ being an 'objector' and being 'exempt' have quite different connotations: ${ }^{223}$

\begin{abstract}
A person might 'object' to something that is commonly accepted ... He is considered an outsider, or renegade; someone who will not pull his weight and join with everyone else ... By contrast, someone who is 'exempt' holds a status that is acknowledged ... A legal exemption acknowledges one's right to have an opinion and act accordingly, without forfeiture of the rights and privileges that are enjoyed by others.
\end{abstract}

Whether refusal via legislatively-mandated processes is framed as a right or an unfortunate necessity, there should logically be a definite disincentive for refusal that does not follow these processes. Unfortunately, conceptualising an appropriate sanction for failure to make a legally supervised choice is no easier than doing so for defiance of a mandatory immunisation law. ${ }^{224}$ Aside from people's general respect for legislation, there is usually little to prevent parents from simply ignoring an exemption process, since legally and illegally un-

${ }^{222}$ See Ministry of Health Public Health Legislation: Promoting Public Health, Preventing Ill Health and Managing Communicable Diseases: Discussion Paper (Wellington, 2002) 87; Ministry of Health (National Health Committee) Review of the Wisdom and Fairness of the Health Funding Authority Strategy for the Immunisation of 'Hard to Reach' Children (Wellington, 1999) 9. See further Australian Government Family Assistance Office "Maternity Immunisation Allowance" <www.familyassist.gov.au> (last accessed 21 September 2005).

${ }^{223}$ Gary Krasner "The Philosophic Exemption" (2002) < http://www.garynull.com> (last accessed 26 September 2005) Electronic un-paginated version available only 'The Distinction Between 'Conscientious' \& 'Philosophical'.

${ }^{224}$ See IV C 1 How do you enforce an immunisation law? and VII B 1 Sanctions and incentives. 
immunised children (and/or their parents) are not treated in a substantively different manner.

People should, in general terms, be less likely to feel compelled to defy a law that requires a decision than one that requires a specific outcome. Perhaps we should not be concerned with parents so fervently opposed to State-mandated immunisation that they will break the law to avoid engaging with an exemption process; such parents would probably be in a small minority and not in any event amenable to persuasion by health professionals. However, de facto opting out could become a significant problem if an exemption process was seen to be unduly demanding.

$2 \quad$ Taking the easy way out

Although it must not be prohibitively difficult to opt out of immunisation, it must not be too easy either. If it is seen as less onerous to get an exemption than to get a child immunised, at least some parents will claim what are known as "exemptions of convenience" - and passive non-immunisation will not be successfully eliminated. ${ }^{225}$ Exemptions of convenience are now considered a serious problem in the United States, especially in jurisdictions like California that have attempted to remove as many limitations on parental autonomy as possible. $^{226}$

The 'free rider' problem is also an ever-present one. Feudtner and Marcuse have asked: $:^{227}$

\footnotetext{
225 See Calandrillo, above n 212, 360 and 412-413.

${ }^{226}$ Daniel A Salmon "Mandatory Immunization Laws and the Role of Medical, Religious and Philosophical Exemptions" (Unpublished commentary, John Hopkins Bloomberg School of Public Health, 2003) 3. See Calandrillo, above n 212, 413, 417 and 432-433.

${ }^{227}$ Chris Feutdner and Edgar K Marcuse "Ethics and Immunization Policy: Promoting Dialogue to Sustain Consensus" (2001) 107 Pediatrics 1158, 1159-1160. See Salmon, above n 226, 2; Calandrillo, above n 212, 361; Arthur Allen "Opposition to Vaccination Programs is Misguided" in William Dudley (ed) Epidemics (Greenhaven Press, San Diego, 1999) $<$ http://galenet.galegroup.com> (last accessed 26 September 2005) Electronic un-paginated version available only 'Mandatory Vaccination Laws'; Diekema, above n 203, 1429.
} 
[S]hould any child (or their family) be allowed to take advantage of a common good (in this case, community immunity against a disease) and potentially put that collective good at risk, even if at an individual level this course might make sense, albeit from a selfish perspective?

Like other 'common goods', population immunity hinges on people's willingness to take both individual and collective interests into account in decision-making. It is imperative that, if opting out is permitted on the basis of concerns about adverse events, adequate resources are devoted to battling complacency about the threat posed by actual diseases. ${ }^{228}$ Even if the risk of disease becomes comparable to the risk inherent in immunisation (as, ideally, it should), ${ }^{229}$ the scales will tip back dramatically if people begin to take that risk for granted.

The difficulty is with avoiding undue pressure upon the minority of parents who have deeply held objections to immunisation, while making it clear that 'opt-out' provisions are not intended to be (and, if population immunity thresholds are to be reached, must not be) relied upon by anyone else. Some commentators believe that this can be achieved through a focus on the content of 'informed refusal', with Salmon suggesting that an exemption law should: ${ }^{230}$

\begin{abstract}
$[R]$ equire parents who are considering philosophical or religious exemptions for their children to attend individual educational counselling provided by a nurse or health educator knowledgeable of vaccine issues, outlining the individual and societal risks of not vaccinating. This approach will ensure ... better-informed parents able to make more meaningful choices ...
\end{abstract}

To legally refuse immunisation in Austratia, for example, parents must obtain a certificate stating that a registered provider has taken them thrêugh a benefit-risk analysis - unless they can prove that they are practising members of

\footnotetext{
${ }^{228}$ See Salmon, above n 226, 2; Calandrillo, above n 212, 359.

${ }^{229}$ See II B 1 Adverse events following immunisation.

230 Salmon, above n 226, 4. See Ross D Silverman "No More Kidding Around: Restructuring Non-Medical Childhood Immunization Exemptions to Ensure Public Health Protection" (2003) 12 Ann Health L 277, 294.
} 
the Church of Christ, Scientist. ${ }^{231}$ The assumption underlying this provision, which is not supported by most of the literature, ${ }^{232}$ appears to be that everyone who does not belong to that church is amenable to persuasion on the basis of scientific information. In any event, though an education requirement may dissuade people from claiming 'exemptions of convenience', it will not hamper those determined to refuse immunisation on grounds that the State may consider to be selfish or irrational.

\section{Drawing the line}

The United States experience is generally looked to by jurisdictions that are considering moving to an informed choice model. However, the basic premise of informed choice - that the substance of a decision is not to be dictated by the State - has only recently become evident in United States immunisation laws. In fact, most states used to limit the possibility of opting out to medical grounds (where a child is contra-indicated for a vaccine or has acquired natural immunity). ${ }^{233}$ This effectively amounted to mandatory immunisation, given broad consensus that there is little benefit in compelling children abnormally at risk to undergo vaccinations. ${ }^{234}$ It was from this starting point that states were driven, as individual freedom of choice began to assume greater prominence, to draft increasingly permissive non-medical grounds for opting out. ${ }^{235}$ As a result, countries like Australia, which have graduated from voluntary immunisation up to 'informed choice', ${ }^{236}$ have in fact adopted an essentially categorical approach which places substantive - not just procedural - limits on people's ability to refuse immunisation.

\footnotetext{
231 Australian Government Family Assistance Office "Maternity Immunisation Allowance" $<$ www.familyassist.gov.au> (last accessed 21 September 2005).

${ }^{232}$ See generally Immunisation Handbook 2002, above n 197, 241-242; McIntyre, Williams and Leask, above n 204, 150-151; Calandrillo, above n 212, 397.

${ }^{233}$ M Craig Smith "A Bad Reaction: A Look at the Arkansas General Assembly's Response to McCarthy v Boozman and Boone v Boozman" (2005) 58 Ark L Rev 251, 251; Calandrillo, above n 212, 382-383; Alan R Hinman and others "Childhood Immunisation: Laws that Work" (2002) 30 JLME 122, 124.

${ }^{234}$ See Calandrillo, above n 212, 412-413.

${ }^{235}$ See Calandrillo, above n 212, 382-383 and 416; Smith, above n 233, 251.

${ }^{236}$ See Australian Government Family Assistance Office "Maternity Immunisation Allowance" $<$ http://www.familyassist.gov.au> (last accessed 21 September 2005).
} 
The issue of which non-medical exemptions should be legally sanctioned, and what burden people should have to discharge to bring themselves within those exemptions, continues to be bitterly controversial. ${ }^{237}$ It is complicated by the fact that debates about the merits of different objections to immunisation are often conducted in the abstract, but must be subjugated to the bottom line of achieving population immunity targets if an exemption scheme is to realise its purpose. In practice, legislation tends to draw a line between some reasons for refusing immunisation, which the State should (or, practically, must) recognise, and others which it must not if population immunity levels are to be sustained. ${ }^{238}$

The two dominant categories of non-medical statutory exemption are 'religious' and 'philosophical'. It is regularly assumed that religious convictions deserve special recognition, not least because their free expression is constitutionally guaranteed. ${ }^{239}$ However, religious exemptions are often claimed within close-knit denominational communities, leading to 'clusters' of unimmunised children that pose serious public health risks. ${ }^{240}$ Further, the definition of a 'religious' objection to immunisation has become an increasingly fraught exercise. ${ }^{241}$ Very few religions actually forbid their members from being immunised. Yet many people do feel that immunisation is incompatible with their personal spiritual convictions; and whether or not those convictions are mandated by, or even connected to, a particular religious denomination is unlikely to affect their sincerity.

So-called 'philosophical' exemptions emerged partly in order to cater for spiritual beliefs that are independent of a particular 'religion', partly for

See generally Calandrillo, above n 212; Salmon, above n 226; Smith, above n 233; Silverman, above n 230; Krasner, above n 223; Ross D Silverman and Thomas May "Private Choice Versus Public Health: Religion, Morality, and Childhood Vaccination Law" (2001) 1 Margins 505.

${ }^{238}$ See Calandrillo, above n 212, 382-383; Salmon, above n 226, 3; Allen, above n 227, 'Mandatory Vaccination Laws'.

239 Yet there is no constitutional right to a religious (or philosophical) exemption from immunization in the United States: Hinman and others, above $n$ 233, 126; Silverman, above $n$ 230,281 .

${ }^{240}$ See Calandrillo, above n 212, 415; Hinman and others, above n 233, 125; Silverman, above n 230, 285; British Medical Association, above n 198, 12.

241 See Calandrillo, above n 212, 414-415; Hinman and others, above n 233, 124-125; Silverman, above n 230, 282-284. 
with State-mandated health interventions. ${ }^{242}$ Although there is, arguably, no principled reason to permit religious but not philosophical exemptions, ${ }^{243}$ the latter can be invoked in an alarming multiplicity of situations, especially given that there is not even an inbuilt (if arbitrary) burden of proof such as having to demonstrate membership of an organised religion. ${ }^{244}$ Many United States jurisdictions will accept an affirmation of 'philosophical' opposition to immunisation on its face, and over half have never refused an exemption request. ${ }^{245}$ Policy-makers must strike a difficult balance between ensuring that parents have "good cause" for claiming an exemption, ${ }^{246}$ and not being seen to discriminate between parents whose opposition to immunisation is equally fervent.

\section{$4 \quad$ Summary}

Once legislation begins to dictate the form that an 'informed refusal' must take, it is a small step to dictating the basis of that refusal. If immunisation must be refused by reference to a legislatively specified ground, the inevitable implication is that there are grounds for opposition to immunisation that will not give rise to a legal entitlement to refuse it. This can only be reconciled with the State's obligation to respect "voluntary, informed and competent" decisions if it is accepted that someone who refuses immunisation on a non-sanctioned ground is necessarily uninformed and/or incompetent. ${ }^{247}$ In reality, as soon as a categorical exemption scheme is implemented, we have moved to a form of genuinely coercive immunisation.

This, arguably, does not mean it must not be considered for New Zealand. At present, the State can give parents appropriate information, but can only hope that they will make their decision on the basis of that information. Implementing an 'informed refusal' requirement would not substantially alter this position, except that parents could be compelled to receive information instead of just

\footnotetext{
${ }^{242}$ See generally Krasner, above n 223.

243 See generally Krasner, above n 223.

${ }^{244}$ See Silverman and May, above n 237, 515-516; Silverman, above n 230, 284-285.

${ }^{245}$ Hinman and others, above n 233, 125. See Salmon, above n 226, 3.

${ }^{246}$ This is the criteria for claiming an exemption in Ohio: Krasner, above n 223, 'Postscript 1'.

${ }^{247}$ See V A The Content of Informed Decisions.
} 
being offered it. Refusal by those determined to take "the path of least resistance" would continue to be tolerated, even if it prevented us from reaching population immunity levels. ${ }^{248}$ A carefully-designed categorical approach, by contrast, might harm no-one. At worst, it would benefit everyone by enabling population immunity levels to be achieved, while harming those whose 'choice' to refuse immunisation was either considered to be selfish and/or irrational, or (in the absolute worst-case scenario) less deeply motivated than the five per cent that could safely be permitted to abstain from an immunisation programme. The political risk associated with prioritising certain grounds for refusing immunisation over others cannot be ignored, but the government that implements an exemption scheme would have to be prepared to draw the line somewhere (and, if necessary, to revise that line) if the opportunity to achieve population immunity was not to be lost. ${ }^{249}$

\section{Risk Communication and Adverse Events}

If the State plays an active role in promoting immunisation as beneficial, it should also take some responsibility for anyone that immunisation actually harms. ${ }^{250}$ At present, New Zealand has a relatively comprehensive framework for both monitoring and remedying, as far as practicable, the tiny but real risk associated with immunisation events. ${ }^{251}$ Although compensation levels are not particularly generous, ${ }^{252}$ anyone who can prove they have been harmed by an immunisation event is entitled to cover under our statutory no-fault accident compensation scheme (ACC). ${ }^{253}$

Arguments that extraordinary levels of compensation should be available for immunisation-related harm because it was incurred in the service of the

\footnotetext{
248 Salmon, above n 226, 3.

249 See generally Salmon, above n 226, 3-4; Calandrillo, above n 212, 418; Hinman and others, above n 233, 127.

${ }^{250}$ See Kempe, above n 217, 49; Calandrillo, above n 212, 408.

251 See Kempe, above n 217, 49.

252 See generally William J Gaine "No-Fault Compensation Systems" (2003) 326 BMJ 997. Compare Calandrillo, above n 212, 408; United States Department of Health and Human Services (Health Resources and Services Administration) "Commonly Asked Questions about The National Vaccine Injury Compensation Program" <http://www.hrsa.gov> (last accessed 30 September 2005).

253 See Injury Prevention, Rehabilitation and Compensation Act 2001, ss 32-34.
} 
public good, as advanced in the United States, ${ }^{254}$ are not persuasive. Immunisation almost always benefits the individual who undergoes it, in addition to the indirect benefits that flow from a decreased societal risk of disease; it cannot be characterised as a 'sacrifice' in the way that, for example, military service can. Even when vaccination causes injury, that injury is usually less severe than the probable outcome of infection with the relevant disease. ${ }^{255}$

It is possible to imagine an unfortunate situation where an injured child's parents had consented to immunisation without full appreciation of the risks involved, whether or not those risks were unusually high for the particular child. Those concerned with exposing arrogant or paternalistic governmental attitudes, among others, might regard the prospect of litigation in such situations as an important accountability mechanism. As the law stands, however, claimants would have to establish that a provider acted with deliberate or reckless disregard for their right to informed consent to have a realistic chance of success in an action for exemplary damages, and courts would be wary of allowing any award of exemplary damages to function as a surrogate compensatory mechanism. ${ }^{256}$

Even where a child is not harmed by immunisation, anger when its risks had been downplayed by a provider would be understandable. However, any system established to address breakdowns in risk communication might be placed under pressure to cater also for those who claimed the benefits of immunisation had been insufficiently stressed, if (for example) an un-immunised child went on to contract a preventable disease. For that matter, people might want to sue the State for failure to maintain population immunity levels when a child for whom vaccination was contra-indicated or ineffective fell victim to disease. It is doubtful whether such claims could be sustained under current law relating to the liability of public actors (although this might change if new legislation was seen to articulate actionable statutory duties in respect of

\footnotetext{
${ }^{254}$ See for example Barbara Loe Fisher "Parents Should be Allowed to Opt Out of Vaccinating Their Children" in Mary E Williams (ed) Vaccinations (At Issue Series, Greenhaven Press, San Diego, 2003) <http://galenet.galegroup.com> (last accessed 26 September 2005) Electronic unpaginated version available only.

${ }^{255}$ See II B 1 Adverse events following immunisation.

${ }^{256}$ See Bottrill v A [2003] 2 NZLR 721, 737 (PC) Lord Nicholls.
} 
immunisation ). ${ }^{257}$ However, if New Zealand adopts an 'opt-out' rather than an 'opt-in' system, the State's power to manipulate public awareness of the benefits and risks of immunisation (and thereby actual coverage rates) will be accurately perceived as having grown; and the likelihood that people will want to blame the State for decisions that turn out to be the wrong ones may grow correspondingly.

Although it is possible to develop internal processes to address the problem of information failures on the part of providers, a more transparent accountability process could be a valuable tool in the struggle to maintain public confidence in an immunisation programme. On the other hand, lynching of individual providers would be unlikely either to improve their performance or their credit rating with the public, and litigation against the State would probably sour more relationships than it would mend.

It is submitted that policy-makers should give consideration, first, to publicly acknowledging that most fully informed people decide to immunise their children, and therefore there is neither need nor justification to manipulate that decision-making process to achieve immunisation targets; secondly, to whether any compensation scheme is likely to mollify those who are convinced that immunisation programmes have the effect of prioritising collective over individual health; ${ }^{258}$ and, thirdly, to effectively publicising an individual avenue of complaint that will vindicate the right to informed consent and expose information failures, without cultivating a culture of blame that undermines the State's genuine interest in the health of its citizens. Exposition of the options for such a forum is beyond the scope of this paper, but a starting point could be the ability of the Health and Disability Commissioner to receive and investigate complaints about breaches of the informed consent provisions in the Code. ${ }^{259}$

257 See generally Stephen Todd (ed) The Law of Torts in New Zealand (3 ed, Brookers, Wellington, 2001) 333-350.

${ }^{258}$ See generally Felicity Lawrence "The Battle Over Immunisation" (10 August 2001) The Guardian <http://www.guardian.co.uk> (last accessed 26 September 2005).

${ }^{259}$ See for example The Health and Disability Commissioner "Informed Consent for Child Receiving Vaccines" (Case Note, 18 September 2002) <www.hdc.org.nz> (last accessed 26 September 2005). 
So far, this paper has assumed (as have the recent Ministry of Health discussion papers) ${ }^{260}$ that any reform that aimed to lift our immunisation coverage levels would do so by imposing identical obligations on all New Zealand parents. However, this assumption is not shared by everyone with an interest in immunisation law reform. In the 2005 election year, the National Party of New Zealand (National) revived a proposal of the 1990s that the strengthening of legal obligations in respect of immunisation should be, at least for now, confined to one section of the population. The receipt of certain social security benefits, it is suggested, could legitimately be conditioned upon the immunisation status of beneficiaries' children. ${ }^{261}$

This section argues that notwithstanding the various justifications advanced for implementing a targeted immunisation law, and the existence of some overseas precedents, capitalising upon the embedded vulnerability of beneficiaries is not defensible in principle and should certainly not be prioritised over other available policy options.

\section{A Why Single Out Beneficiaries?}

\section{$1 \quad$ Discrimination?}

Both the generally-phrased section 19 of BORA and the specific provisions in Part 2 of the Human Rights Act 1993 (HRA) affirm the right of New Zealanders to be free from discrimination upon certain prohibited grounds. Section 21(1)(k)(ii) of the HRA provides that employment status, including being a recipient of a benefit, is one of these grounds. There is, accordingly, a

\footnotetext{
${ }^{260}$ See III D 2 Public health reform.

${ }^{261}$ See Don Brash MP "Welfare Dependency: Whatever Happened to Personal Responsibility?" (Speech to Orewa Rotary Club, Orewa, 25 January 2005) 11 [Orewa Speech]; Katherine Rich MP Saving the Next Generation from Welfare Dependency: Discussion paper $<$ http://www.national.org.nz> (last accessed 24 September 2005) 14-15 [Welfare Dependency Discussion Paper]. For the historical context of the 2005 proposal, see Department of Social Welfare Towards a Code of Social and Family Responsibility: The Response Report (Wellington, 1998) 45-48.
} 
presumption in New Zealand that it is not generally legitimate to impose more onerous obligations upon beneficiaries because they are beneficiaries. ${ }^{262}$

An immunisation law that applied only to beneficiaries could, in general terms, be seen to discriminate against them. More precisely, though, a targeted law would create a distinction between would-be beneficiaries, in that only parents of children whose immunisation status was not legally sanctioned could be penalised. It seems unlikely that immunisation status, per se, could be considered a prohibited ground of discrimination. Section 21(1)(h)(vii) of the HRA does prohibit discrimination by reason of "the presence in the body of organisms capable of causing illness", but this seems designed to protect people who have already become infected with a disease, rather than those who have not guarded themselves against the possibility of infection. The right to refuse medical treatment could be invoked to support an indirect argument that people who choose to exercise it by refusing immunisation cannot legitimately be discriminated against, but only if it was first accepted that the limits placed upon individual autonomy by immunisation laws are incapable of being "demonstrably justified". 263

The question of how immunisation laws can be successfully enforced has continued to trouble policy-makers. ${ }^{264}$ Instinctive confusion about why an immunisation law should be restricted in its scope to one section of the population is, arguably, answerable by the plain fact that the State has more power over beneficiaries than non-beneficiaries. Generally, beneficiaries are simply not in a position - either economically or politically, despite the HRA's guarantee of non-discrimination - to protest a requirement that imposes only upon them. Financial penalties for non-compliance with an immunisation requirement, in particular, are likely to encounter less resistance if the money

\footnotetext{
262 See Child Poverty Action Group Inc "HRC Complaint D1951: Child Poverty Action Group / Child Tax Credit" <http://www.cpag.org.nz> (last accessed 26 September 2005) 2.

263 See New Zealand Bill of Rights Act 1990, ss 5 and 11.

264 See IV C 1 How do you enforce an immunisation law?.
} 
being extracted (or withheld) is seen by the non-beneficiary majority to be the legitimate property of the State in the first place.

If a targeted law was to effectively implement our current policy objective, the number of children whose immunisation it would secure plus the number of currently immunised children would have to equal at least 95 per cent of the New Zealand population. ${ }^{265}$ Whether or not there are enough unimmunised children of beneficiaries to make this equation work, National has not actually proposed a mandatory immunisation requirement - as might be contemplated, for example, for an extreme religious sect unanimously opposed to immunisation. Instead, it is suggested that beneficiaries should be forced by an 'opt-out' law to make an informed decision about immunisation, ${ }^{266}$ meaning that the law could guarantee only the addition of passively non-immunised beneficiary children to our immunisation statistics. Given that passive nonimmunisation is not a phenomenon solely limited to beneficiaries, this could not single-handedly close our immunisation 'gaps'.

This said, National's proposal could be seen as an important step in the right direction, ${ }^{267}$ in that there is considerable evidence to suggest that beneficiary children are not only more likely to be passively un-immunised than non-beneficiary children, but are disproportionately at risk of contracting vaccine-preventable diseases. ${ }^{268}$ Notwithstanding that it would probably be more accurate to describe our immunisation 'gaps' as between low- and high-income families than beneficiary and non-beneficiary families, ${ }^{269}$ there is a fairly sound pragmatic argument (which could be refined by the successful implementation of

\footnotetext{
265 See II A 2 Population immunity.

${ }^{266}$ National Party of New Zealand "Bad Day Steve?" (13 March 2003) Media Release; Orewa Speech, above n 261, 11.

${ }^{267}$ See Welfare Dependency Discussion Paper, above n 261, 15.

268 See Ministry of Health (National Health Committee) Review of the Wisdom and Fairness of the Health Funding Authority Strategy for the Immunisation of 'Hard to Reach' Children (Wellington, 1999) 1 and 7 [National Health Committee Review]; Ministry of Health (National Immunisation Programme) Immunisation in New Zealand: Strategic Directions 2003-2006 (Wellington, 2003) 2 [Immunisation in New Zealand]. See generally L C Kerpelman, D B Connell and W J Gunn "Effect of a Monetary Sanction on Immunization Rates of Recipients of Aid to Families with Dependent Children" (2000) 284 JAMA 53; Tim O'Donovan, Karen McMillan and Heather Worth "An Employment Barrier: The Health Status of DPB Recipients' Children" (2004) 22 SPJNZ 97.

${ }^{269}$ See National Health Committee Review, above n 268, 1 and 7; Immunisation in New Zealand, above n 268, 2.
} 
the National Immunisation Register) ${ }^{270}$ for focusing scarce public health resources on the immunisation of beneficiary children. However, unless and until it can be established that specific beneficiary parents are both necessarily and exclusively accused of 'inertia' in respect of immunisation, arguments that beneficiaries present an efficient target do not provide a principled justification for a targeted law.

\section{Reciprocal obligations}

All this is not to say that no principled justification has been advanced for limiting coercive immunisation initiatives to beneficiaries. Lawrence Mead's complaint that the world beneficiaries inhabit "is economically depressed yet privileged in one sense, in that it emphasizes their claims and needs almost to the exclusion of obligations", ${ }^{271}$ underpins National's avowal that there is a choice to be made by beneficiaries entering a "contract" with the state: ${ }^{272}$ between accepting both State support and "an expectation that certain things will be done in return", ${ }^{273}$ or ceasing to enjoy that support. ${ }^{274}$ In the immunisation context, this translates into an argument that beneficiaries have no right to expect the State to help them bring up their dependent children if they do not fulfil their 'obligation' to seriously consider having those children immunised. ${ }^{275}$

\footnotetext{
${ }^{270}$ See III D 1 National Immunisation Register.

${ }^{271}$ Lawrence M Mead Beyond Entitlement: The Social Obligations of Citizenship (Macmillan, New York, 1986) 2.

${ }_{272}$ Judith A Davey (ed) Another New Zealand Experiment: A Code of Social and Family Responsibility (Institute of Policy Studies, Wellington, 2000) 32. See Ruth Smithies "Beyond Belief: The Social Responsibility Dimension" (Speech to Sea of Faith Conference, Havelock North, 6-8 October 2000) Electronic un-paginated version available only 'The Draft Code of Social and Family Responsibility'.

${ }^{273}$ This is described by Katherine Rich MP as a key component of National's ideal welfare system: Welfare Dependency Discussion Paper, above n 261, 13.

${ }^{274}$ See Jonathan Boston "Morals, Codes and the State: Reflections on 'Another New Zealand Experiment" in Davey, above n 272, 168, 179. See further Robert Stephens "Social Policy and Benefit Reform" (Paper presented to IIR Seminar on Successful Government Policy: Designing, Implementing and Evaluating, Wellington, 24 October 2001) 14.

${ }^{275}$ See Don Brash MP "Brash Responds to Maharey" (31 January 2005) Media Release. See generally Jonathan Boston "Social Justice and the Welfare State" in Jonathan Boston, Paul Dalziel and Susan St John (eds) Redesigning the Welfare State in New Zealand: Problems, Policies, Prospects (Oxford University Press, Auckland, 1999) 20, 36.
} 


\section{B Immunisation as a Reciprocal Obligation}

There seem to be two potentially conflicting messages underpinning National's proposal. On one hand, there is Don Brash MP's insistence that all parents have obligations to ensure that children are immunised (albeit the source of these 'obligations' is not entirely clear) and that "it is about time New Zealanders made it clear that this form of child neglect is unacceptable". ${ }^{276}$ The only way in which this argument can provide support for a targeted law is if we define 'New Zealanders' not as parents (from all walks of life) who do immunise their children, but as non-beneficiary parents who have the right to make things clear to beneficiaries while tolerating those in their midst who are presumptively guilty of the same 'form of child neglect'.

On the other hand, it seems from a 2005 discussion paper that it is the process of making a choice about immunisation, rather than the immunisation outcome for a particular child, which is National's primary concern. ${ }^{277}$ The entrenched dependence of beneficiaries upon the State is perceived by National to be connected to a lack of "personal responsibility". ${ }^{278}$ Rather than contributing to the diminution of this responsibility by unconditionally guaranteeing financial support, the State has "an opportunity, if not an obligation" to work to re-instil it by ensuring that beneficiaries make active choices about their and their family's future. ${ }^{279} \mathrm{~A}$ legal framework which either made immunisation decisions at the societal level or permitted beneficiaries to ignore immunisation altogether would be counterproductive.

This argument might be appealing, if it were not for the fact that immunisation is, ultimately, not about parents but about their children. Regarding immunisation as an 'opportunity' to hone the decision-making capabilities of beneficiary parents carries with it an acceptance that those who fail to make a choice about immunisation should have to take 'responsibility' for the consequences of their actions. However, the way in which this is logically done

\footnotetext{
${ }^{276}$ Don Brash MP "Brash Responds to Maharey" (31 January 2005) Media Release.

${ }^{277}$ See Welfare Dependency Discussion Paper, above n 261, 15.

${ }^{278}$ See generally Orewa Speech, above n 261.

279 Welfare Dependency Discussion Paper, above n 261, 13.
} 
is through reducing the level of financial support available to parents; and whatever this does to parents, it will almost certainly have the flow-on effect of punishing the children for whose benefit the National Immunisation Programme was originally created. ${ }^{280}$

\section{$1 \quad$ Sanctions and incentives}

Even leaving children out of the equation, some commentators have found the thought of subjecting beneficiaries to behavioural conditions under threat of the withdrawal of State support morally abhorrent. Claiming that beneficiaries are "sufficiently obligated by poverty", ${ }^{281}$ it has been suggested that those who are lacking "the necessities of human life and dignity" 282 must receive them without stigma in order to enjoy the right "to share to the full in the social heritage and life of a civilized being." 283 Only when this right is realised "can we encourage all citizens to fulfil their potential and contribute to the common good". 284

Yet it is the likelihood of further disadvantaging children who are already disproportionately at risk of disease which is, arguably, most concerning. It is not generally thought that New Zealand's benefit rates are so high that they can be safely 'trimmed' as a sanction for non-compliance with an immunisation requirement. ${ }^{285}$ On the contrary, Robert Stephens warned in 2003 that "[u]ntil there are increases in the level of generosity to families with dependent children in New Zealand, adverse outcomes for children are lively to bedevil the country for years to come." 286

\footnotetext{
${ }^{280}$ Compare IV C Practical Considerations. But see Orewa Speech, above n 261, 8: "Nobody, and certainly not the National Party, wants to make children suffer for the mistakes of their parents". ${ }^{281}$ Mead, above n 271, 201.

${ }^{282}$ Methodist Mission (South Island) Social Comment from the Mission: Towards A Code of Social and Family Responsibility (submission to Department of Social Welfare, 1998) Electronic un-paginated version available only.

${ }^{283}$ Ramesh Mishra (ed) Society and Social Policy: Theories and Practice of Welfare (2 ed, Macmillan, London, 1981) 24.

${ }^{284}$ Methodist Mission (South Island), above n 282.

${ }^{285}$ See Robert Stephens "Poverty, Family Finances and Social Security" in Boston, Dalziel and St John (eds), above n 275, 238, 256.

${ }^{286}$ Robert Stephens "The Level of Financial Assistance to Families with Dependent Children: A Comparative Analysis" (2003) 20 SPJNZ 173, 194 (emphasis added). See further Ministry of
} 
Bearing in mind that there is little empirical research on the connection between benefit sanctions and immunisation coverage, Don Brash MP's assertion that the "threat" of sanctions may be all that is needed to secure compliance with immunisation requirements is partially supported by one significant United States study. ${ }^{287}$ This study was conducted in the aftermath of a relaxation of federal welfare rules that encouraged a number of states to experiment with targeted immunisation laws. ${ }^{288}$ It found that families who were aware of the prospect of sanctions were significantly more likely to immunise their children, and only 17 of 1500 families needed to be given formal warnings for noncompliance. However, 11 of those families went on to receive benefit cuts, and six lived with reduced benefits for six months or longer: parental abrogation of 'personal responsibility' was compounded, for 18 children, by concrete financial hardship. $^{289}$

To avoid the appearance of making "poor families poorer", ${ }^{290}$ the enforcement of targeted immunisation laws can be couched in terms of 'incentives' rather than 'sanctions'. An incentive could be conceptualised as a expression of gratitude for participation in a civic endeavour, and would aim to attract those in the grip of parental inertia while avoiding pressure on parents actively opposed to immunisation. The recently implemented Australian Maternity Immunisation Allowance, a one-off payment for children under two years of age, is an example of an 'incentive' that offers an independent complement to the main source of family assistance. ${ }^{291}$ However, unlike the subsidiary child-care benefit (which may be denied for non-compliance with immunisation requirements, so operates as a 'sanction'), the Allowance is available to beneficiaries and non-beneficiaries alike. ${ }^{292}$

Social Development New Zealand's Agenda for Children: Making Life Better for Children (Wellington, 2002) 24.

${ }^{287}$ Don Brash MP "Brash Responds to Maharey" (31 January 2005) Media Release. See Kerpelman, Connell and Gunn, above n 268, particularly at 59.

${ }^{288}$ Kerpelman, Connell and Gunn, above n 268, 53-54.

${ }^{289}$ Kerpelman, Connell and Gunn, above n 268, 56.

${ }^{290}$ Rt Hon H Clark MP (27 April 1993) 534 NZPD 14859 (Question for Oral Answer).

291 Australian Government Family Assistance Office "Maternity Immunisation Allowance" $<$ http://www.familyassist.gov.au> (last accessed 21 September 2005).

${ }^{292}$ Australian Government Family Assistance Office "Maternity Immunisation Allowance" $<$ http://www.familyassist.gov.au> (last accessed 21 September 2005); Australian Government 
There is no sound reason for limiting an immunisation 'incentive' to beneficiaries, unless it is assumed that only beneficiaries will be swayed by an offer of money. Underlying this would have to be an assumption either that beneficiaries are not capable of registering the excellent non-financial reasons for participating in immunisation, or that their straitened financial circumstances do not permit them to object to being effectively bribed. If the latter, then using the terminology of 'incentives' is not so much a concession that beneficiaries should not be denied an adequate standard of living as an acceptance that it is permissible to maintain benefits at rates where beneficiaries will find it difficult to refuse even money that comes with strings attached. We are back to an acceptance that society has no obligation to guarantee support to those who will not behave in certain ways.

Although National's proposal is that all beneficiaries with dependent children would be subject to an immunisation requirement, ${ }^{293}$ it is the Domestic Purposes Benefit (DPB) that bears the weight of attempts at justification: ${ }^{294}$

[T] o make it clear that the DPB is being provided primarily as a way of helping and nurturing children, and to recognize the mutual obligation involved in welfare, it will be a requirement that those receiving the DPB present their preschool children for all appropriate vaccinations (unless they have a conscientious objection ...) ...

There are several difficulties with this. First, any implication that the relationship between child, parent and the State could be conceptualised as an employment one (where the State can impose any conditions of employment that it feels would produce a better product) is dangerous. As discussed above, it is generally accepted that the care of children is a quintessentially private activity,

Centrelink "How much Maternity Immunisation Allowance do I get?" <www.centrelink.gov.au> (last accessed 21 September 2005).

${ }^{293}$ Orewa Speech, above n $261,11$.

294 Orewa Speech, above n 261, 11. 
and that parental autonomy from State interference is usually in the interests of children. $^{295}$

Secondly, the explicit focus on the DPB's purpose (to enable parents to do the 'job' of parenting) exposes the artificiality in enforcing the responsibilities of parenthood through the welfare system. It seems to imply that other benefits (such as the Sickness Benefit) are not provided 'as a way of helping and nurturing children', which begs the question of why the State can attach conditions to do with parenting to them. Yet National appears to have recognised that it would be illogical to tolerate worse health outcomes for children just because their parents receive a different category of benefit. It would be interesting to see if the 'parenting' justification would change if separate benefit categories were collapsed, as the Labour government has proposed, into a universal single benefit. ${ }^{296}$ Would it be suggested that all benefits can be conceptualised as payments for rendering the service of responsible parenting? If so, could the same argument not be made, for example, in the case of tax relief for "hardworking New Zealanders" with dependent children? 297

Finally, justifying an immunisation requirement by reference to the obligations of parenthood is problematic in that once the State begins enumerating these obligations in prescriptive rather than proscriptive terms (beyond the accepted baseline of providing the necessaries of life), ${ }^{298}$ it is difficult to know where to stop. As the New Zealand Health Trust has observed, immunisation cannot simply be equated to good parenting: ${ }^{299}$

If the Ministry of Health wants to ... see who is doing their bit to prevent ill health, perhaps they should establish a register that lists those who eat five plus servings of fresh fruit and vegetables per day, or ... parents who ensure that their children get sufficient sleep each day.

\footnotetext{
295 See II D 3 Children and V B 2 The 'right' of parents to make immunisation decisions.

296 See Hon Steve Maharey MP, Minister for Social Development and Employment "Simplified Benefit System Roll-Out Begins in May" (22 February 2005) Media Release.

${ }_{298}^{297}$ See Don Brash MP "Getting Ahead with National" (22 August 2005) Media Release.

${ }^{298}$ See Crimes Act 1961, s 152.

299 New Zealand Health Trust Public Health Legislation Discussion Paper (submission to Ministry of Health, 2003) 17.
} 
Arguably, the greatest irony of targeted immunisation laws is that they have the effect of compromising the individual freedom of beneficiary parents (which may be a deliberate quid pro quo for their reliance on others' money), while prioritising the health of their children over the health of non-beneficiary children who are permitted to remain passively non-immunised. How can National deny that their proposal would disadvantage the children of 'hardworking' parents? Only through claiming that passive non-immunisation is not a concern for non-beneficiary children. Why? Because their parents are, fundamentally, better at their 'job' than beneficiaries. Despite National's insistence that "many beneficiaries are great parents, overcoming real problems in their past", ${ }^{300}$ it is difficult to shake the impression that their targeted behavioural policies rest upon a dim view of the personal qualities of welfare recipients. $^{301}$

\section{To Obligate as Others are Obligated}

National's claim that conditioning benefit receipt upon immunisation would be giving effect to societal expectations about parenting and the subjugation of individual interests, where necessary, to the public good is demonstrably flawed. In particular, their belief that "it is a parent's choice whether to vaccinate or not, but that it is every parent's obligation to make a choice", 302 is not borne out by their immunisation policy. Even assuming society does place this 'obligation' on every parent, the implication is that every parent is not, should not and possibly could not be 'obligated' to the point of compulsion, but only those whose dependence upon taxpayer support provides an "opportunity" for directive intervention. ${ }^{303}$

\footnotetext{
${ }^{300}$ Orewa Speech, above n 261, 4.

301 See generally Sue Bradford MP (Green Party Social Development Spokesperson) "Brash and Maharey in Bidding War over Beneficiaries" (4 February 2005) Media Release; Davey, above n $272,82-83$; Russell Brown " $20^{\text {th }}$ February 1998" <http://nznews.net.nz/hardnews $>$ (last accessed 26 March 2005) Weblog.

302 Welfare Dependency Discussion Paper, above n 261, 15.

${ }^{303}$ Welfare Dependency Discussion Paper, above n 261, 13. See Brown, above n 301.
} 
Mead, whose articulation of "civic conservatism" shares much at the abstract level with National's perspective on welfare, ${ }^{304}$ would regard this implication as antithetical to the supposed aim of 'reciprocal obligation', which is to eliminate the "passivity" that inhibits beneficiaries from functioning as full members of a free society. ${ }^{305}$ In Mead's view, to "obligate the dependent as others are obligated is essential to [the social goal of] equality, not opposed to it." 306 A targeted immunisation law would require beneficiaries not only to be 'good' parents, whatever that may mean, but to be better parents than nonbeneficiaries, who remain free to refuse or ignore immunisation. In this respect, its effect would not be to distribute the burden of participation in immunisation equitably between beneficiaries and non-beneficiaries, ${ }^{307}$ but rather to burden beneficiaries disproportionately as a kind of reprisal for perceived past failures.

If immunisation is (like ensuring that children eat their vegetables) not considered important enough to constitute a prerequisite to responsible citizenship, legislation that infringes upon the personal freedom of beneficiaries in the guise of enforcing societal expectations cannot be justified. If, on the other hand, immunisation (like school attendance) is considered to be that important, then it is impossible to defend legislation that effectively applies one standard of 'responsible citizenship' to beneficiaries and another to non-beneficiaries.

\footnotetext{
${ }^{304}$ See Mead, above n 271, 250.

${ }^{305}$ Mead, above n 271, 220 (emphasis removed from original).

${ }^{306}$ Mead, above n 271, 12 (emphasis added).

307 The equitable distribution of immunisation coverage is a common point of focus for commentators: see for example Chris Feutdner and Edgar K Marcuse "Ethics and Immunization Policy: Promoting Dialogue to Sustain Consensus" (2001) 107 Pediatrics 1158, 1159; Daniel A Salmon "Mandatory Immunization Laws and the Role of Medical, Religious and Philosophical Exemptions" (Unpublished commentary, John Hopkins Bloomberg School of Public Health, 2003) 2; Immunisation in New Zealand, above n 268, vi.
} 
As this paper has demonstrated, immunisation policy does "contemplate numerous complex, contentious, and controversial themes". ${ }^{308}$ The inherent difficulties in reconciling immunisation, as a medical intervention performed upon an individual, with immunisation, as a global public health initiative with implications for all citizens, cannot be overstated. For example, the fact that immunisation is a "counterintuitive biological process" that includes a measurable element of risk must be set against the interest of everyone in the suppression and (potentially) eradication of communicable disease. ${ }^{309}$ The need to ensure that health consumers have the maximum possible latitude in decisionmaking must be balanced against the spectres of inertia and misinformation, which can undermine the quality of individual immunisation decisions. And, of course, our collective responsibility to safeguard the life chances of New Zealand children must be squared with the high value we place upon cohesive and selfsustaining families.

New Zealand's current coverage rates do not reflect the broad national and international consensus about the great value of childhood immunisation. In abstract terms, this represents a failure to translate policy into reality; more concretely, it means that preventable diseases continue to cause needless suffering and death. To date, the law has played a comparatively muted role in the delivery of our National Immunisation Programme. There seems no reason why this should continue, given that immunisation laws have successfully boosted coverage rates in many other Western countries. However, to be both stable and effective, any proposal for immunisation law reform must grapple with the delicate balance between individual freedom and the public good.

308 Ross D Silverman "No More Kidding Around: Restructuring Non-Medical Childhood Immunization Exemptions to Ensure Public Health Protection" (2003) 12 Ann Health L 277, 278. See above $\mathrm{n} 1$ and accompanying quotation.

${ }^{309}$ Arthur Allen "Opposition to Vaccination Programs is Misguided" in William Dudley (ed) Epidemics (Greenhaven Press, San Diego, 1999) < http://galenet.galegroup.com> (last accessed 26 September 2005) Electronic un-paginated version available only 'Vaccination and its Critics'. 
Of the three options for reform considered in this paper, two are arguably unworkable because they require, or will be perceived to require, unacceptable encroachment upon the freedom of some or all individuals. The first option involves making the essentially utilitarian decision that the benefits associated with population immunity must take precedence over the harm associated with over-riding opposition to immunisation, and implementing this decision by means of a universal immunisation requirement that would be avoidable only upon medical grounds. Although there are sound arguments for conceptualising vaccinations as a public duty of all who can receive them, the idea of forcing parents to submit their children to immunisation programmes has always been sharply divisive. In the absence of either a significant shift in public perceptions leading to the evaporation of the anti-immunisation lobby or brutal enforcement provisions, it is not a realistic option for New Zealand.

The second option involves taking advantage of the embedded vulnerability of one section of the population, by enacting targeted laws that place the recipients of social security benefits under more onerous obligations with respect to immunisation than other parents. This has little appeal in either principle or practice. On its own, a targeted initiative would be unlikely to close our immunisation 'gaps'. Further, even if the basic premise of the 'reciprocal obligation' of beneficiaries is accepted, it is difficult to construct immunisation as an obligation of responsible citizenship without concluding that the State should be prepared to enforce that obligation for all New Zealand parents.

While the prioritisation of individual choice in respect of immunisation may eventually prove an insurmountable obstacle to lifting us over the population immunity threshold, the basic thesis of this paper is that allowing individuals to make immunisation decisions is both constitutionally desirable and probably necessary to ensure continued support for the National Immunisation Programme. How can our law be strengthened without sacrificing this commitment? Through a focus, it is suggested, upon those parents who are not implacably opposed to immunisation but who nonetheless have not granted the informed consent required to secure the immunisation of their children. The fundamental difficulty with New Zealand's current 'opt-in' system is that parents 
are free to refuse immunisation on the basis of sketchy or no information, or even to ignore it altogether. Creating a legal presumption in favour of immunisation at the point of school-entry could overcome this form of parental inertia by recasting the role of parents in terms of a right to make an informed decision to opt out of, rather than into, the national programme. Parents would not be permitted to make that decision without at least some understanding of the importance that New Zealand as a society places on raising immunisation coverage levels.

In theory, if the individual decision-making process was perfected, it seems that New Zealand's immunisation targets could be achieved. Therefore, requiring all parents to make an informed decision to refuse immunisation would achieve the desired social policy end without the oppressive implications of a genuinely mandatory immunisation programme. If, however, the number choosing to abstain from immunisation passed the five per cent threshold, fresh consideration would need to be given as to, first, whether the government's support for immunisation continued to reflect informed public opinion, and, secondly, whether the ongoing expenditure of effort to protect the interests of a few at the expense of all was sustainable. 


\section{BIBLIOGRAPHY}

\section{PRIMARY SOURCES}

\section{A Table of Cases}

Bottrill v A [2003] 2 NZLR 721 (PC).

Gillick v West Norfolk Health Authority [1985] 3 All ER 402 (HL(E)).

Jacobson v Massachusetts (1905) 197 US 11.

Prince v Massachusetts (1944) 321 US 158.

$R v$ Jefferies [1994] 1 NZLR 290 (CA).

Re C (Welfare of Child: Immunisation) [2003] EWCA Civ 1148.

Re C and F (children) (immunisation) [2003] All ER (D) 179 (HC).

Re J (an infant): B and Bv D-G of Social Welfare [1996] 2 NZLR 134 (CA).

Rogal v Smith [2003] NZFLR 75 (FC).

\section{B Table of Legislation}

Care of Children Act 2004.

Crimes Act 1961.

Health and Disability Commissioner (Code of Health and Disability Services Consumers’ Rights) Regulations 1996.

Education Act 1989.

Health (Immunisation) Regulations 1995.

Health Act 1956.

Health and Disability Commissioner Act 1994.

Human Rights Act 1993.

Injury Prevention, Rehabilitation, and Compensation Act 2001.

New Zealand Bill of Rights Act 1990.

Privacy Act 1993. 
Convention on the Rights of the Child (20 November 1989) 1577 UNTS 3.

International Covenant on Civil and Political Rights (19 December 1966) 999 UNTS 171.

International Covenant on Economic, Social and Cultural Rights (19 December 1966) 993 UNTS 3.

Universal Declaration of Human Rights (10 December 1948) UNGA Resolution 217 A (III).

\section{Parliamentary Materials}

Rt Hon H Clark MP (27 April 1993) 534 NZPD 14859.

\section{Government Publications}

$1 \quad$ New Zealand

Department of Social Welfare Towards a Code of Social and Family Responsibility: The Response Report (Wellington, 1998).

Ministry of Health (National Health Committee) Review of the Wisdom and Fairness of the Health Funding Authority Strategy for the Immunisation of 'Hard to Reach' Children (Wellington, 1999).

Ministry of Health (National Immunisation Programme) Immunisation in New Zealand: Strategic Directions 2003-2006 (Wellington, 2003).

Ministry of Health Consent in Child and Youth Health: Information for Practitioners (Wellington, 1998).

Ministry of Health Immunisation Handbook 2002 (Wellington, 2002).

Ministry of Health Overview of the National Immunisation Register (Wellington, 2004).

Ministry of Health Progress on Health Outcome Targets 1998 (Wellington, 1998).

Ministry of Health Public Health Legislation Review: A New Public Health Legislative Framework: Discussion Document (Wellington, 1998).

Ministry of Health Public Health Legislation: Promoting Public Health, Preventing Ill Health and Managing Communicable Diseases: Discussion Paper (Wellington, 2002). 
Ministry of Health Well Child Tamariki Ora Health Book (Revised, Wellington, 2005).

Ministry of Social Development New Zealand's Agenda for Children: Making Life Better for Children (Wellington, 2002).

$2 \quad$ Australia

Family Assistance Office "Maternity Immunisation Allowance" $<$ http://www.familyassist.gov.au> (last accessed 21 September 2005).

Centrelink "How much Maternity Immunisation Allowance do I get?" <www.centrelink.gov.au> (last accessed 21 September 2005).

Health Insurance Commission "About the Australian Childhood Immunisation Register" <www.hic.gov.au> (last accessed 21 September 2005).

\section{$3 \quad$ United Kingdom}

Department of Health "Draft Chapter 3 Consent" in Immunisation Against Infectious Disease (Draft revised version, London, 2004).

Department of Health Immunisation Against Infectious Disease (London, 1996).

$4 \quad$ United States

Department of Health and Human Services (Centers for Disease Control and Prevention) "For Parents: Why Immunize?" < http://www.cdc.gov> (last accessed 26 September 2005).

Department of Health and Human Services (Centers for Disease Control and Prevention) "Six Common Misconceptions about Vaccination and How to Respond to Them" <http://www.cdc.gov> (last accessed 26 September 2005).

Department of Health and Human Services (Health Resources and Services Administration) "Commonly Asked Questions about the National Vaccine Injury Compensation Program" <http://www.hrsa.gov> (last accessed 30 September 2005).

Department of Health and Human Services (National Vaccine Program Office) "Immunization Laws" <http://www.cdc.gov> (last accessed 26 September 2005).

\section{$\mathbb{E} \quad$ Submissions on Government Publications}

Methodist Mission (South Island) Social Comment from the Mission: Towards a Code of Social and Family Responsibility (submission to Department of Social Welfare, 1998). 
New /caland I läalth T (submission to

estimonials

Pediatries "Testimony. Statement of Samuel L Katz MD

e on Government Reform. U.S. House of Representatives. $<$ ww.aap.org adrocacy> (last accessed 13 September

are Dependency: Whatever Happened to Personal

(Speech to Orewa Rotary Club, Orewa, 25 January

d Belief: The Social Responsibility Dimension" (Speech Conference. Havelock North, 6-8 October 2000).

\section{and Weblogs}

Mandatory Vaccination"

nj.bmjjoumals.com> (last accessed 24 September 2005)

W Weblog.

een Party Social Development Spokesperson) "Brash and dding War over Beneficiaries" (4 February 2005) Media

Responds to Maharey" (31 January 2005) Media Release.

ng Ahead with National" (22 August 2005) Media Release.

ebruary 1998"<http://nznews.net.nz/hardnews> (last

arch 2005) Weblog.

$2005 "<$ http://www.kiwiblog.co.nz> (last accessed 25

5) Weblog.

IP, Minister for Social Development and Employment nefit System Roll-Out Begins in May" (22 February 2005)

Zealand "Bad Day Steve?" (13 March 2003) Media

\section{nunications}

stry of Health, to the author (24 March 2005) Email er@moh.govt.nz>.
F Speeche's and

American Academyo of to the Commit Alugust 31000 $20(05)$.

Brash, I)on MP “Welt Responsibility" $20(05)$.

Smithies, Ruth "Beyo to Sea of Faith

\section{G Media Release}

Beutels, Philippe "On $<$ http://www.b Rapid Respons

Bradford, Sue MP (Gr Maharey in $\mathrm{Bi}$ Release.

Brash, Don MP "Brash

Brash, Don MP "Getti

Brown, Russell " $20^{\text {th }} \mathrm{F}$ accessed $26 \mathrm{Mi}$

Farrar, David "Jan 26 September 200

Maharey, Hon Steve N "Simplified Be Media Release.

National Party of New Release.

H

Personal Comn

Baker, Gabrielle, Mini $<$ Gabrielle.Bak 
Interview with Mary Ryan, Regional Immunisation Coordinator, Hutt Valley

District Health Board (the author, Wellington, 24 August 2005).

\section{SECONDARY SOURCES}

A Texts

Boston, Jonathan, Paul Dalziel and Susan St John (eds) Redesigning the Welfare State in New Zealand: Problems, Policies, Prospects (Oxford University Press, Auckland, 1999).

British Medical Association Childhood Immunisation: A Guide for Healthcare Professionals (British Medical Association Publications Unit, London, 2003).

Davey, Judith A (ed) Another New Zealand Experiment: A Code of Social and Family Responsibility (Institute of Policy Studies, Wellington, 2000).

Detel, W and others Oxford Textbook of Public Health Volume 1 (3 ed, Oxford Medical Publications, Oxford, 1997).

Dewar, John Law and the Family (Butterworths, London, 1989).

Dudley, William (ed) Epidemics (Greenhaven Press, San Diego, 1999).

Eekelaar, John Family Law and Social Policy (2 ed, Weidenfeld and Nicolson, London, 1984).

Kempe, Ann Immunisation Programs in NZ, USA, Canada, UK and Finland: Lessons for Australia and South Australia (1998 Churchill Fellowship Report, Canberra, 1999).

Mead, Lawrence M Beyond Entitlement: The Social Obligations of Citizenship (Macmillan, New York, 1986).

Mishra, Ramesh (ed) Society and Social Policy: Theories and Practice of Welfare (2 ed, Macmillan, London, 1981).

Palmer, Geoffrey and Matthew Palmer Bridled Power: New Zealand's Constitution and Government (4 ed, Oxford University Press, Melbourne, 2004).

Todd, Stephen (ed) The Law of Torts in New Zealand (3 ed, Brookers, Wellington, 2001).

Williams, Mary E (ed) Vaccinations (At Issue Series, Greenhaven Press, San Diego, 2003). 
Paterson, Ron (Chief Advisor, Services, Ministry of Health) "Legal and Ethical

Dilemmas" (Paper presented to Consent and Child Health workshop, Wellington, 6 August 1998).

Rich, Katherine MP Saving the Next Generation from Welfare Dependency:

Discussion Paper <http://www.national.org.nz> (last accessed 24 September 2005).

Stephens, Robert "Social Policy and Benefit Reform" (Paper presented to IIR

Seminar on Successful Government Policy: Designing, Implementing and Evaluating, Wellington, 24 October 2001).

C Articles

American Academy of Pediatrics (Childhood Immunization Support Programme) "Letter from American Academy of Pediatrics President, Carol Berkowitz, MD, FAAP" <www.cispimmunize.org> (last accessed 13 September 2005).

American Academy of Pediatrics (Committee on Bioethics) "Informed Consent, Parental Permission, and Assent in Pediatric Practice" (1995) 95 Pediatrics 314.

Australian Early Childhood Association "Immunisation" $<$ http://www.earlychildhoodaustralia.org.au $>$ (last accessed 24 September 2005).

Boseley, Sarah "Cubans Tell NHS the Secret of £7 a Head Healthcare" (2 October 2000) The Guardian <http://www.guardian.co.uk> (last accessed 20 September 2005).

Bradley, P "Should Childhood Immunisation Be Compulsory?" (1999) 25 JME 330.

Calandrillo, Steve P "Vanishing Vaccinations: Why are So Many Americans Opting Out of Vaccinating Their Children?" (2004) 37 U Mich J L Reform 353.

Child Poverty Action Group Inc "HRC Complaint D1951: Child Poverty Action Group / Child Tax Credit" <http://www.cpag.org.nz> (last accessed 26 September 2005).

Diekema, Douglas S and American Academy of Pediatrics (Committee on Bioethics) "Responding to Parental Refusals of Immunization of Children" (2005) 115 Pediatrics 1428.

Dyer, Clare "Judge Overrules Mothers' Objections to MMR Vaccine" (2003) 326 BMJ 1351. 
Dyer, Clare "Mothers Lose Anti-MMR Battle" (31 July 2003) The Guardian $<$ http://www.guardian.co.uk> (last accessed 26 September 2005).

Feudtner, Chris and Edgar K Marcuse "Ethics and Immunization Policy: Promoting Dialogue to Sustain Consensus" (2001) 107 Pediatrics 1158.

Gaine, William J "No-Fault Compensation Systems” (2003) 326 BMJ 997.

Green, Aphra "Immunisation in New Zealand: Patient Autonomy, Informed Consent, and the Code of Rights" (2002) 1 NZ Students' Law Jnl 203.

Hinman, Alan R and others "Childhood Immunisation: Laws that Work" (2002) 30 JLME 122.

Immunization Action Coalition "It's Federal Law! You Must Give your Patients Current Vaccine Information Statements (VISs)" $<$ http://www.immunize.org> (last accessed 24 September 2005).

James, Colin "Making Welfare Work in the Troubled 2000s" (20 May 2003) The New Zealand Herald <http://www.colinjames.co.nz> (last accessed 26 September 2005).

Kerpelman L C, D B Connell and W J Gunn "Effect of a Monetary Sanction on Immunization Rates of Recipients of Aid to Families with Dependent Children" (2000) 284 JAMA 53.

Krasner, Gary "The Philosophic Exemption" (2002) <http://www.garynull.com> (last accessed 26 September 2005).

Lawrence, Felicity "The Battle Over Immunisation" (10 August 2001) The Guardian <http://www.guardian.co.uk> (last accessed 26 September 2005).

Loe Fisher, Barbara (National Vaccine Information Center) "The Moral Right to Conscientious, Personal Belief or Philosophical Exemption to Mandatory Vaccination Laws" (1997) <http://www.909shot.com> (last accessed 26 September 2005).

Meikle, James "Court Win for Fathers in MMR Jabs Fight" (14 June 2003) The Guardian <http://www.guardian.co.uk> (last accessed 26 September 2005).

McFadden, Johnjoe "Injecting Some Sense" (21 January 2002)

$<$ http://www.guardian.co.uk> (last accessed 20 September 2005).

McIntyre, Peter, Alison Williams and Julie Leask "Refusal of Parents to Vaccinate: Dereliction of Duty or Legitimate Personal Choice?" (2003) 178 MJA 150 (editorial). 
Mountain State Centers for Independent Living "Support Mandatory Immunizations!" <http://www.mtstcil.org> (last accessed 15 September 2005).

National Health Committee "Action on Immunisation of New Zealand's 'Hard to Reach' Children” <http://www.nhc.org.nz> (last accessed 24 September 2005).

New Zealand Anti-Vivisection Society "Vaccinations: General - The Conspiracy" <http://www.health.org.nz/artltitle.html> (last accessed 24 September 2005).

New Zealand Press Association "Child Immunisations Could be Required Before DPB granted" (5 February 2003) < http://www.childcareonline.co.nz> (last accessed 26 September 2005).

O’Donnell, Kath " $\operatorname{Re} C$ (Welfare of Child: Immunisation): Room to Refuse? Immunisation, Welfare and the Role of Parental Decision-Making" (2004) $16 \mathrm{C}$ Fam 213.

O’Donovan, Tim, Karen McMillan and Heather Worth "An Employment Barrier: The Health Status of DPB Recipients' Children” (2004) 22 SPJNZ 97.

Robinson, Ann “Cracks in Public Confidence" (11 August 2004) The Guardian <http://www.guardian.co.uk> (last accessed 20 September 2005).

Ross, Tara "Parents Flock to Infect Kids at "Pox Parties"' (7 August 2005) The Manawatu Standard <http://www.stuff.co.nz> (last accessed 26 September 2005).

Salmon, Daniel A "Mandatory Immunization Laws and the Role of Medical, Religious and Philosophical Exemptions" (Unpublished commentary, John Hopkins Bloomberg School of Public Health, 2003).

Sexton, Kerry and others "Proceedings of the Meningococcal Vaccine Strategy World Health Organization Satellite Meeting, 10 March 2004, Auckland, New Zealand" (2004) 117 NZMJ 1.

Silverman, Ross D "No More Kidding Around: Restructuring Non-Medical Childhood Immunization Exemptions to Ensure Public Health Protection" (2003) 12 Ann Health L 277.

Silverman, Ross D and Thomas May "Private Choice Versus Public Health: Religion, Morality, and Childhood Vaccination Law" (2001) 1 Margins 505.

Smith, M Craig “A Bad Reaction: A Look at the Arkansas General Assembly's Response to McCarthy v Boozman and Boone v Boozman" (2005) 58 Ark L Rev 251. 
Stephens, Robert "The Level of Financial Assistance to Families with

Dependent Children: A Comparative Analysis" (2003) 20 SPJNZ 173.

The Health and Disability Commissioner "Informed Choice - Not a Matter of Negotiation" (9 February 2005) <http://www.hdc.org.nz> (last accessed 26 September 2005).

The Health and Disability Commissioner "Informed Choice and the Rights of Children" (10 February 2000) <http://www.hdc.org.nz> (last accessed 26 September 2005).

The Health and Disability Commissioner "Informed Consent for Child Receiving Vaccines" (Case Note, 18 September 2002) <www.hdc.org.nz> (last accessed 26 September 2005).

The Health and Disability Commissioner "What Do I Need to Know about 'Informed Consent'?" (30 June 2005) <http://www.hdc.org.nz> (last accessed 26 September 2005).

Vermeersch, E “Individual Rights Versus Societal Duties" (1999) 17 Vaccine S14.

Webster, Paul “A Polio-Free World?” (2005) 366 The Lancet 359.

\section{Websites}

Australian Government Family Assistance Office $<$ http://www.familyassist.gov.au> (last accessed 23 September 2005).

Australian Government Centrelink < http://www.centrelink.gov.au> (last accessed 23 September 2005).

Australian Government Health Insurance Commission <http://www.hic.gov.au> (last accessed 24 September 2005).

Immunisation Advisory Centre <http://www.immune.org.nz $>$ (last accessed 24 September 2005).

Meningococcal B - Be wise, immunise $<$ http://www.immunise.moh.govt.nz $>$ (last accessed 12 September 2005).

Michigan Opposing Mandatory Vaccines < http://www.momvaccines.org > (last accessed 26 September 2005).

Ministry of Health <http://www.moh.govt.nz > (last accessed 20 September 2005).

Ministry of Social Development $<$ http://www.msd.govt.nz $>$ (last accessed 20

September 2005). 
National Network for Immunization Information $<$ http://www.immunizationinfo.org > (last accessed 26 September 2005).

The Health and Disability Commissioner <http://www.hdc.org.nz> (last accessed 26 September 2005).

The Immunisation Awareness Society Inc <http://www.ias.org.nz $>$ (last accessed 24 September 2005).

United States Centers for Disease Control and Prevention $<$ http://www.cdc.gov $>$ (last accessed 26 September 2005).

Vaccine Safety Net <www.who.int/immunization_safety $>$ (last accessed 13 September 2005). 


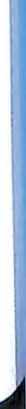

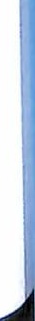

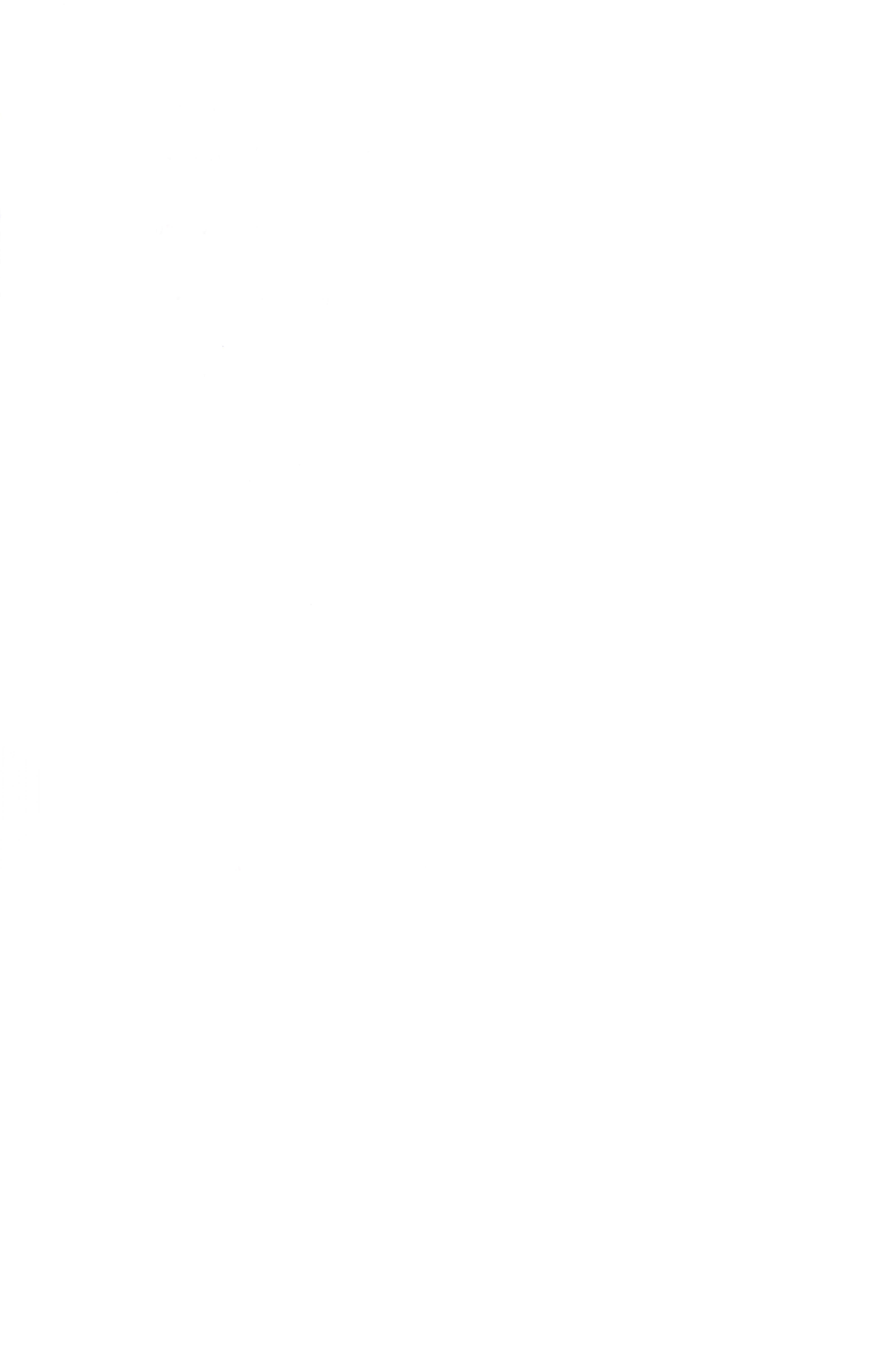


AS741
VUW
A66
K41
2005

AS741
VUW
A66
K41
2005

AS74
VUW
A66
K41
2005

AS74
VUW
A66
K41
2005

AS74
VUW
A66
K41
2005
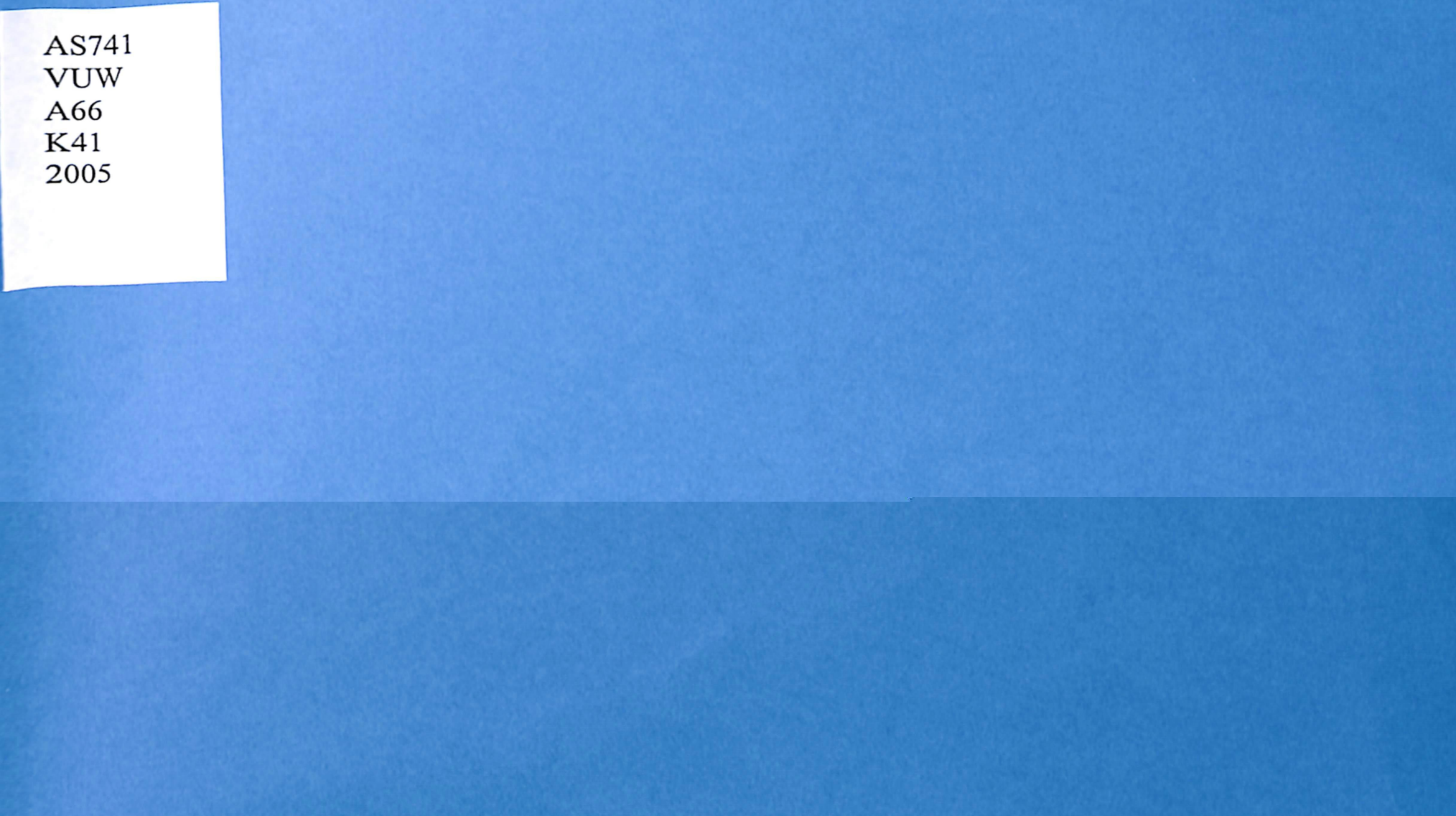


\section{$24 / 11-2012$}

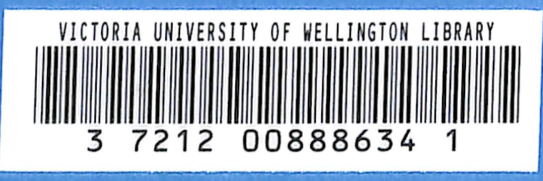

